\title{
Nanobody: A Small Antibody with Big Implications for Tumor Therapeutic Strategy
}

\author{
Shuyang Sun ${ }^{1,2}$ \\ Ziqiang Ding' \\ Xiaomei Yang ${ }^{1,3}$ \\ Xinyue Zhao ${ }^{1,3}$ \\ Minlong Zhao ${ }^{1,2}$ \\ Li Gao ${ }^{1,3}$ \\ Qu Chen ${ }^{1,2}$ \\ Shenxia Xie ${ }^{1,4}$ \\ Aiqun Liu' \\ Shihua Yin (D) \\ Zhiping $X u^{5}$ \\ Xiaoling $\mathrm{Lu}^{\mathrm{I}, 2}$ \\ 'International Nanobody Research \\ Center, Guangxi Medical University, \\ Nanning, Guangxi, 53002I, People's \\ Republic of China; ${ }^{2}$ School of \\ Stomatology, Guangxi Medical University, \\ Nanning, Guangxi, 53002I, People's \\ Republic of China; ${ }^{3}$ School of Preclinical \\ Medicine, Guangxi Medical University, \\ Nanning, Guangxi, 53002I, People's \\ Republic of China; ${ }^{4}$ Department of \\ Pharmacology, Guangxi Medical \\ University, Nanning, Guangxi, 53002I, \\ People's Republic of China; ${ }^{5}$ Australian \\ Institute for Bioengineering and \\ Nanotechnology, University of \\ Queensland, St Lucia, QLD, 4072, \\ Australia
}

Correspondence: Xiaoling Lu Nanobody Research Center, Guangxi Medical University, Nanning, Guangxi, 53002I, People's Republic of China $\mathrm{Tel} / \mathrm{Fax}+86$ 77I-2387 $5 \mathrm{I} 8$

Email luxiaoling@gxmu.edu.cn

Zhiping Xu

Australian Institute for Bioengineering and Nanotechnology, University of Queensland, St Lucia, QLD, 4072, Australia

Email gordonxu@uq.edu.au
This article was published in the following Dove Press journal:

International Journal of Nanomedicine

\begin{abstract}
The development of monoclonal antibody treatments for successful tumortargeted therapies took several decades. However, the efficacy of antibody-based therapy is still confined and desperately needs further improvement. Nanobodies are the recombinant variable domains of heavy-chain-only antibodies, with many unique properties such as small size $(\sim 15 \mathrm{kDa})$, excellent solubility, superior stability, ease of manufacture, quick clearance from blood, and deep tissue penetration, which gain increasing acceptance as therapeutical tools and are considered also as building blocks for chimeric antigen receptors as well as for targeted drug delivery. Thus, one of the promising novel developments that may address the deficiency of monoclonal antibody-based therapies is the utilization of nanobodies. This article provides readers the significant factors that the structural and biochemical properties of nanobodies and the research progress on nanobodies in the fields of tumor treatment, as well as their application prospect.
\end{abstract}

Keywords: nanobody, drug delivery, immunotherapy, CAR-T, tumor treatment

\section{Introduction to Antibody and Nanobody}

Since 1975, monoclonal antibodies have been triumphantly applied to the diagnosis and management of various diseases. For example, chimeric antibodies, humanized antibodies, as well as all-human antibodies, and miniaturized genetic engineering antibodies, have manifested expanding application prospects. Nevertheless, the strengths of smaller size are, upon most occasions, counteracted by descending stabilization, leading to polymerization (especially single-chain variable fragment, $\mathrm{scFv}$ ), lower affinity binding, and problems in mass production. ${ }^{1}$ Therefore, nanobody $(\mathrm{Nb})$ discovered in 1993 seems to be able to address the problems.

$\mathrm{Nb}$ is a naturally deleted light chain antibody in the peripheral blood of alpaca. The acquisition of $\mathrm{Nb}$ first needs to select a camelid animal for immunization, which will probably take 5-10 weeks. As shown in Figure 1A-F, the effector $\mathrm{B}$ cells are obtained from the plasma by extracting the peripheral lymph blood from the immunized camel, then the total RNA is extracted from the effector $\mathrm{B}$ cells and the cDNA sequence of the fragment is obtained by the reverse transcription-PCR technology, so primary PCR products can be used as templates for amplification. Phage display is employed to screen afterward and enrich $\mathrm{Nb}$ phage with specific binding ability from the nanobody library which is subsequently established after the structure of the phage vector. Eventually, the $\mathrm{Nb}$ expression system is built to express proteins and function verification is carried out. Although the preparation process is relatively complicated, with the development of 


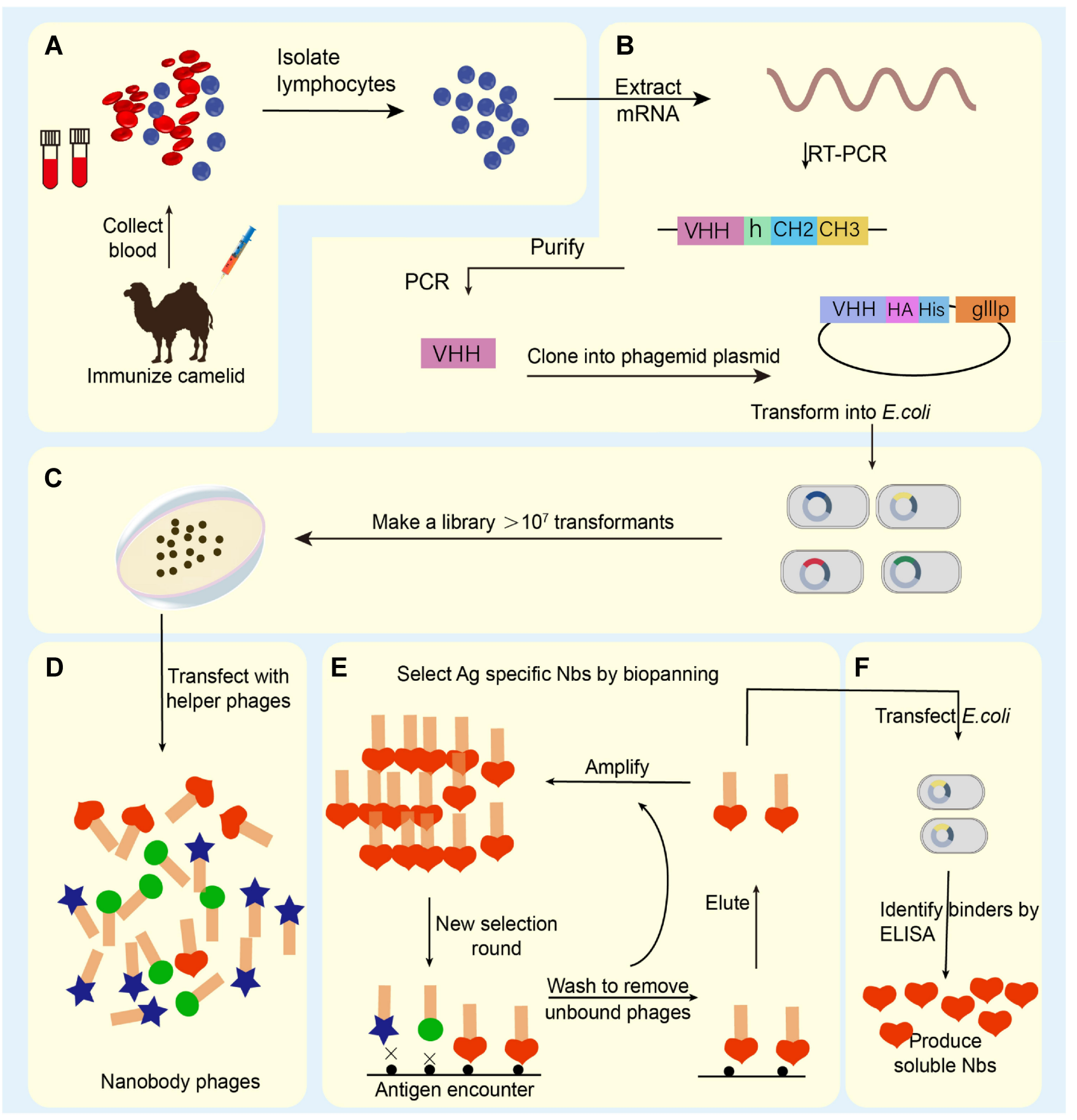

Figure I Schematic overview of nanobody generation. (A) Extracting a cDNA from peripheral blood obtained from a camelid after immunized. (B) Extracting Total mRNA and reversely transcribing into cDNA, then amplifying the $\mathrm{VHH}$, the phage display vector and the $\mathrm{VHH}$ are digested by restriction enzymes, and the two fragments are connected. (C) Constructing natural or immune camelid-derived nanobody libraries. (D-F) Obtaining antigen-specific nanobody by multiple screening.

Notes: Adapted with permission of Future Science Ltd, from Novel therapy based on camelid nanobodies. Unciti-Broceta JD, Del Castillo T, Soriano M, Magez S, GarciaSalcedo JA. Ther Deliv. 4(10):1321-1336, copyright 2013; permission conveyed through Copyright Clearance Center, Inc. ${ }^{29}$

molecular biology technologies such as phage display technology, the screening steps of $\mathrm{Nb}$ are being gradually optimized. $^{2}$

Compared with the traditional antibody IgG, which includes one heavy chain variable region VHH connects with two traditional $\mathrm{CH} 2$ and $\mathrm{CH} 3$ constant domains, and its molecular weight is only half of that of the traditional antibody. ${ }^{3,4}$ The cloned antibody containing only a heavy chain variable region named $\mathrm{Nb}$ or single-domain antibody (sdAb), has identical stability and excellent antigen binding vitality in comparison to the initial heavy chain antibody (HcAb). ${ }^{5,6}$ Due to its high specificity, strong stability, and 
top affinity, it has generated extraordinary accomplishments in the field of antibodies. ${ }^{7,8}$ It is no exaggeration to say that $\mathrm{Nb}$ has been extensively used in biochemical mechanisms, structural biology, diagnosis and treatment of tumors and other diseases. $^{9,10}$ This article will evaluate the basic characteristics of $\mathrm{Nb}$ and its research progress in tumor treatment, and look forward to its application prospect.

\section{Structure and Physicochemical Features of Nanobody Basic Structure of Nanobody}

$\mathrm{Nb}$ is the minimum known inartificial antigen-specific binding functional fragment, which consists of approximately 120 amino acids, with a crystal is $2.5 \mathrm{~nm}$ in diameter, 4 $\mathrm{nm}$ in length and merely $12 \sim 15 \mathrm{~kb}$ in weight (Figure 2D). ${ }^{6}$ The molecular weight is smaller than the traditional monoclonal antibody mAb $(\sim 150 \mathrm{~kb})$, Fab fragment $(\sim 55 \mathrm{~kb})$ or $\mathrm{HcAb}(\sim 90 \mathrm{~kb})$ in Figure $2 \mathrm{~A}-\mathrm{C}$. Furthermore, the variable region domain can form a domain antibody called nanobody by itself. ${ }^{11}$ Previous research found that these nanobodies can be genetically engineered from the heavy-chain antibody derived from camelids or cartilaginous fish, whose immune systems had already evolved into high-affinity V-like domains so that intramolecular disulfide bonds with stability were not for the demand. ${ }^{12-15}$ Therefore, $\mathrm{Nb}$ has a stronger and faster tissue penetration ability and can reach dense tissues such as solid tumors to play a role. At the same time, due to renal filtration, the half-life of $\mathrm{Nb}$ in the blood is also relatively shorter, in some cases can avoid the accumulation of toxicity.

$\mathrm{Nb}$ consists of three antigenic complementary determining regions (complementarity determining region, CDR) and four frame regions (frame region, FR). Among them, three $\mathrm{CDR}$ are the binding regions of $\mathrm{Nb}$ to the antigen, while the traditional antibody needs six CDR to maintain the binding to the antigen. Compared with monoclonal antibodies, $\mathrm{Nb}$ showed considerable or even stronger antigen-binding ability. ${ }^{16,17}$ In addition, the longer amino acid sequences of CDR1 and CDR3 of $\mathrm{Nb}$ make up for the loss of antigenbinding ability caused by the loss of light chain to some extent. After receiving antigen stimulation, the production of $\mathrm{Nb}$ mainly depends on somatic hypermutation, so a longer CDR sequence also means more antibody diversity. Crystallographic studies have shown that longer CDR3 regions give $\mathrm{Nb}$ a stronger ability to bind antigens, which can bind to antigenic epitopes that cannot be reached by traditional antibodies. ${ }^{18}$ Sequence alignment showed that the $\mathrm{VH}$ domain of $\mathrm{Nb}$ was highly homologous to that of human immunoglobulin IgG, but there were significant differences between FR2 and CDR3 regions. Previous studies have shown that repeated administration of $\mathrm{Nb}$ will not cause any humoral and cellular immune response. ${ }^{19-21}$ but whether long-term repeated use of $\mathrm{Nb}$ drugs will cause its immunogenicity to the body remains to be studied. ${ }^{22}$
A

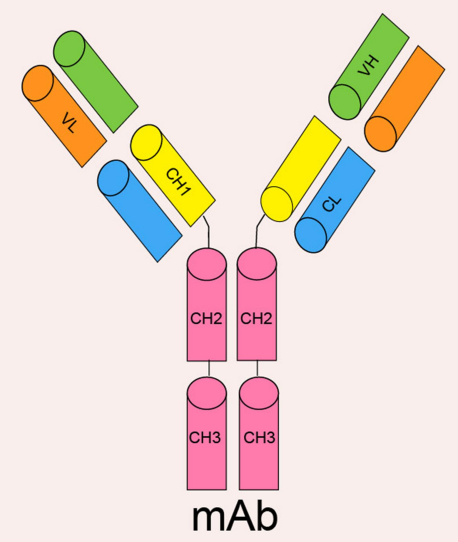

B

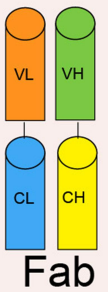

C

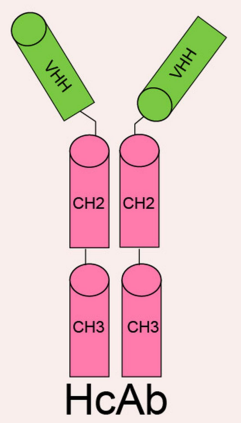

D

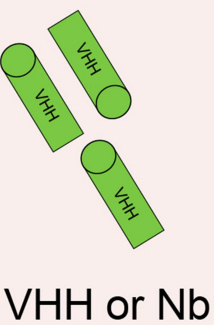

Figure 2 The various antibody formats: (A) mAb (monoclonal antibody); (B) Fab (fragment antigen binding); (C) $\mathrm{HcAb}$ (camel heavy-chain antibody); (D) VHH or $\mathrm{Nb}$ (nanobody). Adapted from Yang X, Xie S, Yang X, et al. Opportunities and Challenges for Antibodies against Intracellular Antigens. Theranostics. 20I9;9(25):7792-7806. Available from: https://www.thno.org/v09p7792.htm. Creative Commons license and disclaimer available from: http://creativecommons.org/licenses/by/4.0/legalcode. ${ }^{165}$ 


\section{Characteristics of Nanobody (Compared with Antibody)}

A key feature of nanobody is its good solubility. In traditional antibodies, there are a large number of hydrophobic residues in the FR2 region where $\mathrm{VH}$ interacts with VL (Figure 3B). ${ }^{23}$ In the absence of light chain VL, the hydrophobic residues on the surface of $\mathrm{VH}$ are exposed and aggregation is easy to occur in vitro. ${ }^{24}$ These hydrophobic residues were replaced by hydrophilic residues in VHH, which reduced the aggregation ability of $\mathrm{VHH}$ and improved the water solubility of VHH (Figure 3B and C). Other characteristics of nanobody include, (1) high thermostability, $\mathrm{Nb}$ can maintain $80 \%$ activity at $37^{\circ} \mathrm{C}$ for one week. ${ }^{25}$ After denaturation at $90^{\circ} \mathrm{C}, \mathrm{Nb}$ can restore its natural active conformation. ${ }^{26} \mathrm{Nb}$ can also resist the effects of denaturants, proteases and extreme pH.12 (2) short development cycle, $\mathrm{Nb}$ can be manufactured in batch production of large quantities via microbial systems, whereas the production of traditional monoclonal antibodies requires a eukaryotic expression system, the process is technologically elaborate and expensive to maintain. (3) the various screening approaches, in addition to the traditional methods of immunization, the production of $\mathrm{Nb}$, using natural antibody library and antibody library synthesized in vitro can overcome the shortcomings of immunization. ${ }^{27,28}$ What is more, its low molecular weight, high affinity and strong antigen recognition ability, $\mathrm{Nb}$ has more advantages than traditional antibodies in tumor diagnosis and treatment. In recent years, $\mathrm{Nb}$ has indeed shown promising potentials in the treatment of tumors. ${ }^{29}$

\section{Nanobody as Tumor Therapeutic Agent}

The traditional antibody has played a great role in the field of tumor diagnosis and treatment and opened the era of targeted therapy. At present, it has already been widely used as one of the primary methods in the guide of crizotinib therapy and has created considerable socioeconomic benefits. ${ }^{30}$ On condition that traditional antibodies contain Fc domains, and cancer cells can be killed by antibody-dependent cell-mediated cytotoxicity (ADCC)

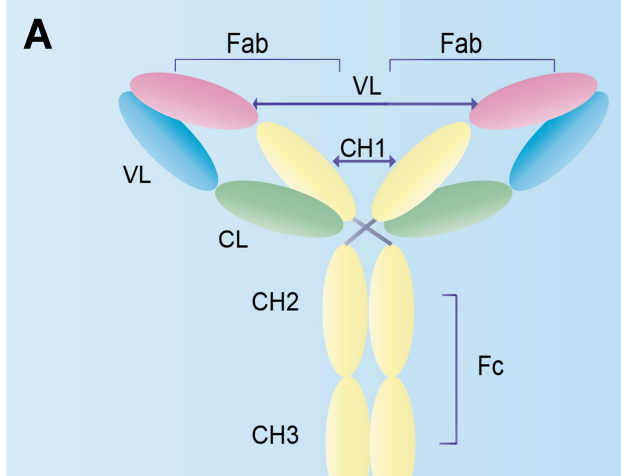

Conventional $\lg G$ antibody
B

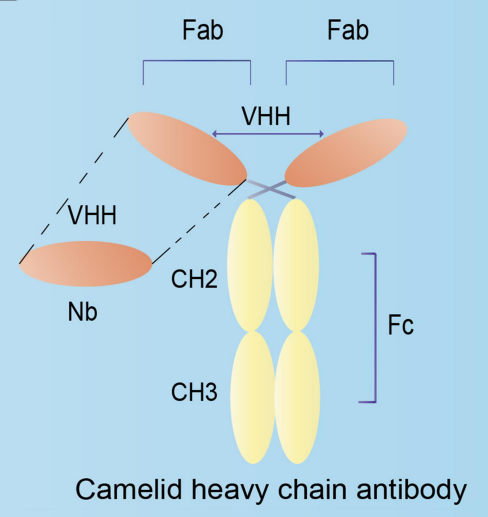

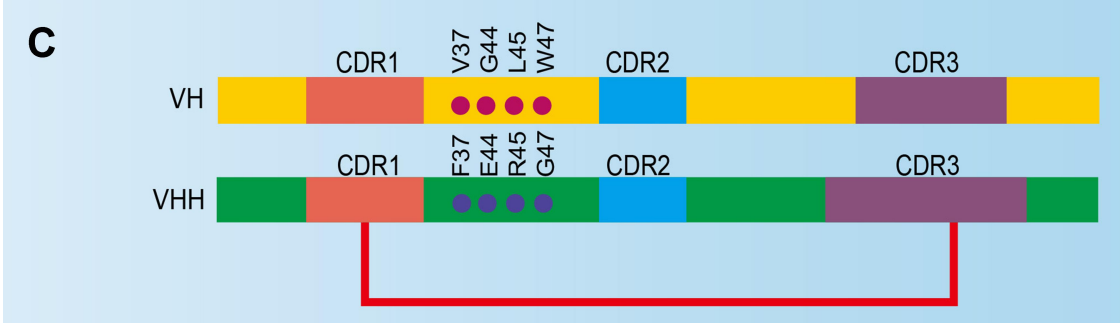

Figure 3 Comparison between traditional IgG antibody and camelid heavy-chain antibody. (A) Traditional IgG antibody has two identical heavy chains, consisting of VH, $\mathrm{CHI}, \mathrm{CH} 2$, and $\mathrm{CH} 3$ domains, and two identical light chains, consisting of $\mathrm{VL}$ and $\mathrm{CL}$ domains. (B) Camelid heavy-chain antibody contains one $\mathrm{VHH}$ and two constant domains $(\mathrm{CH} 2$ and $\mathrm{CH} 3)$. $\mathrm{A} \mathrm{Nb}$ is the $\mathrm{VHH}$ domain of heavy-chain antibody obtained by recombinant gene technology. (C) The difference in amino acid sequence of $\mathrm{VH}$ and $\mathrm{VHH}$. The average length of the CDRI and CDR3 is better in the VHH domain than in the VH domain. The dotted line indicates the additional disulfide bond between CDRI and CDR3 of the VHH domain. The Numbering of the international ImMunoGeneTics-IMGT information system is pointed out. Adapted from J Biotechnol, 74(4), Muyldermans S. Single domain camel antibodies: current status. 277-302, Copyright (200I), with permission from Elsevier. ${ }^{196}$ 
and complement-dependent cytotoxicity (CDC). ${ }^{31}$ However, the molecular weight of a traditional antibody is as high as $150 \mathrm{~kb},{ }^{32}$ and its penetration ability is poor, so it is sometimes difficult to reach the target tissue. Relatively speaking, the molecular weight of $\mathrm{Nb}$ is small, so it is easy to penetrate the barrier to reach the cancerous tissue. For the moment, according to the above-mentioned characteristics of $\mathrm{Nb}, \mathrm{Nb}$ drugs have been developed for different tumors (B-cell lymphoma, multiple myeloma, malignant glioma, colon cancer, liver cancer and breast cancer, etc.), ${ }^{33}$ which are widely related to tumor tracer diagnosis, direct targeted therapy, treatment carriers and so on.

\section{Nanobody Targeting Classic Tumor-Associated Receptor}

$\mathrm{Nb}$ can be used as a new generation of drugs for the treatment of human diseases because of their unique pharmacological and physicochemical properties. $\mathrm{Nb}$ is able to validly couple to the concaves on the appearance of protein. ${ }^{34}$ Furthermore, Nb has the capability of functioning in cells to target intracellular antigens. ${ }^{35,36} \mathrm{Nb}$ has strong stability in extreme situations and can pass through the hemato-encephalic barrier. ${ }^{37}$ Because of its insusceptibility to pepsin, oral administration may be used to enhance stomach function and improve gastrointestinal illness. ${ }^{38,39}$ In addition, $\mathrm{Nb}$ can easily be engineered for the new development of particular and efficient cures for certain diseases such as rotavirus infection. ${ }^{40}$ So far, apart from the application of $\mathrm{Nb}$ in microbial infection, treatment of neurodegenerative diseases, anti-inflammation and immune regulation, the research results in tumor diagnosis and treatment are particularly outstanding.

EGFR (Epidermal Growth Factor Receptor) is highly expressed in almost most tumors and monoclonal antibodies have been produced on therapeutic drugs to target EGFR through 20 years' endeavor in human malignancies. ${ }^{41,42}$ However, mAb cannot easily penetrate tumor tissues due to the limitation of large molecular weights. Oliveira et al developed a probe based on anti-EGFR nanobody 7D12 which was linked with the near-infrared fluorophore IRDye800CW and made a comparison with an anti-EGFR $\mathrm{mAb}$ cetuximab. 7D12-IR allowed tumor microenvironment visualizable approximately only 30 minutes post injection, but no signal was detectable around the tumor site for cetuximab-IR. ${ }^{43}$ Therefore, results highlight that the $\mathrm{Nb}$ is considered superior to the $\mathrm{mAb}$ in penetrating tumor tissue for optical molecular imaging. Moreover, EGFR specific antibodies screened from the $\mathrm{Nb}$ library can block the binding of EGF to its receptors, thus inhibiting EGFRmediated motility of signal transduction and proliferation of cells. ${ }^{44,45}$ Its polyvalent antibody might suffice to further facilitate the appetency of EGFR Nb. Meanwhile, in order to prolong its half-life in vivo, the dual-valent $\mathrm{Nb}$ of EGFR or coupled with mouse serum albumin can better inhibit the growth of tumors. ${ }^{46}$ Oliveira et al injected the nanobody targeting EGFR into mice, found that it specifically combined with EGFR in tumor cells, and detected that the expression of EGF was down-regulated. ${ }^{47}$ Roovers et al and Sebastian et al have confirmed in animal experiments that the specific nanobody targeting EGFR can reach the tumor body more effectively, and the growth of solid tumor cells can be more effectively inhibited by competing with epidermal growth factor to bind EGFR site. ${ }^{48,49}$ Tijink et al found that the bivalent nanobody targeting EGFR or mouse serum albumin was coupled. It can better inhibit the growth of tumor cells. ${ }^{50}$

Carcinoembryonic antigen (CEA) was highly expressed in epithelial-derived cancer cells, but not or at a low level in normal cells. ${ }^{51}$ Moreover, in normal colon tissue, CEA is only expressed on the epithelium of the lumen, which is impenetrable by IgG antibody. ${ }^{52} \mathrm{CEA} \mathrm{Nb}$ fuses with $\beta$-lactamases to localize $\beta$-lactamases inside the tumor and kill the tumor in situ by catalyzing $\beta$-lactam anti-tumor prodrugs to produce cytotoxic drugs. ${ }^{53}$ This antibody-dependent enzyme prodrug therapy system can cause specific transplant tumor decline or cure, and has a strong targeting for tumor therapy. ${ }^{54}$ It has been proved by experiment that this conjugate can establish a nonadverse effect tumor treatment method by selectively activating anticancer precursors. ${ }^{53}$ In addition, CEA $\mathrm{Nb}$ is more sensitive in clinical diagnosis and treatment of lung cancer than traditional antibodies. ${ }^{55}$

Mucin 1 (MUC1) is not only overexpressed in a variety of tumor tissues but also glycosylation does not completely expose the concealed epitopes under normal conditions, which has become the target of immune diagnosis and therapy. ${ }^{56,57}$ Rahbarizadeh F's team screened MUC1 $\mathrm{Nb}$ from the immune library for the first time. ${ }^{58}$ The $\mathrm{Nb}$ was well expressed in Escherichia coli, ${ }^{59}$ Pichia pastoris, ${ }^{60}$ tobacco, ${ }^{61}$ and the rest. Then, they used MUC1's Nb to construct chimeric antigen receptor modified $\mathrm{T}$ cells (CAR-T cells) and introduced the T cells into tumor cells to play the role of cellular immunity. ${ }^{62}$ 
Hypoxia-inducible factor-1 $\alpha$ (HIF- $1 \alpha)$ is a crucial transcription factor that accommodates endosomatic oxygen homeostasis. ${ }^{63,64}$ It promotes the proliferation and metastasis of tumor cells by regulating angiogenesis and glucose metabolism through downstream target genes. ${ }^{65,66}$ The GROOT group screened the specific antibody against the oxygen-dependent domain (ODD) of HIF-1 $\alpha$ from the unimmunized camel-derived $\mathrm{Nb}$ library. ${ }^{67}$ The antibody down-regulated the transcriptional activity of HIF-1 $\alpha$ to the target gene by binding to the ODD domain of HIF- $1 \alpha$. Since then, they have made an in-depth study on the conditional inactivation of HIF-1 $\alpha$ with HIF-1 $\alpha$ specific $\mathrm{Nb}$. Through the binding of HIF-1 $\alpha$ nanobody to the active site of PAS-B, the amount of HIF-1 (only the dimerization of HIF- $1 \alpha$ and HIF- $1 \beta$ and tying up the target gene has transcriptional activation to the target gene) can be reduced, thus inhibiting the proliferation and metastasis of tumors.

Polyvalent antibodies targeting two or more different tumor-associated antigens at the same time can theoretically improve the anti-tumor efficacy to a certain extent. The multivalent $\mathrm{Nb}$ effect of anti-VEGF coupled with antiangiopoietin 2 (ANG2) $\mathrm{Nb}$ was better than that of their monovalent $\mathrm{Nb}^{68}$ The polyvalent antibody MaAbNA formed by the coupling of anti-EGFR $\mathrm{Nb}$ with two antiHER2 is being verified in vivo. ${ }^{69}$ The recombinant protein formed by the fusion of anti-EGFR $\mathrm{Nb}$ and highly permeable cancer-specific associative peptide iRGD can enhance the anti-tumor clinical efficacy, and improve the permeability of tumor tissue..$^{70}$ Besides, through the guidance of signal sequence, direct targeted delivery of $\mathrm{Nb}$ in vivo has also become one of the methods to raise the efficacy of $\mathrm{Nb}$. For example, linking anti-CapG $\mathrm{Nb}$ to the signal sequence T3s of EspF (E. coli-secreted protein F), intracellular delivery of tumor cells by bacteria with type III protein secretion, or targeted delivery of tumor cells through SP-neurokinin-1 receptor pathway have achieved good results. ${ }^{71}$

\section{Nanobody Targeting New Tumor-Associated Receptor}

In addition to the above common tumor targets. For example, the two $G$ protein-coupled receptors (GPCRs) C-X-C chemokine receptor type 4 (CXCR4) and atypical chemokine receptor 3 (ACKR3) are members of the class A chemokine GPCR family and embody biological targets for human immunodeficiency virus (HIV) infection, cancerous growth, and auto-immune and inflammatory disorders. ${ }^{72}$ Binding of synthetic nanobody to the intracellular transducer pocket of the receptor stabilized the great conformational change profiles of activated GPCRs. ${ }^{73}$ ACKR3, which involved in stages of tumorigenesis, there is no reported description of mAbs against ACKR3 in the development of preclinical or clinical research currently, whereas the ACKR3 targeting nanobody NB1-NB3 effectively reduced tumor growth and improved overall survival in a xenograft model system by using the head and neck cancer $22 \mathrm{~A}$ cell lines which highly express ACKR3. The preliminary experimental results suggested that the NB1-NB3 nanobody did not affect cell-cycle progression but restrained the excretion of angiogenic factor CXCL1 ${ }^{74}$ Therefore, it demonstrated that nanobody is a potential alternative to mAb advancing GPCR targeting under the circumstances that there are still no selective antibodies approved against ACKR3, thus ACKR3 targeting nanobodies are expected to reverse the immunosuppressive cancer microenvironment and use as the new clinic therapeutics or research tools.

Other new targets also provide a basis for $\mathrm{Nb}$ therapy. CTLA-4 (cytotoxic T lymphocyte-associated antigen-4) is a member of a family of immunoglobulin-related receptors and serves as a critical regulator of $\mathrm{T}$ cell responses to tissues. ${ }^{75}$ Decreasing CTLA-4 function by nanobody blockade should activate self-reactive $\mathrm{T}$ cells and alter Treg homeostasis. Our previous study suggested that the CTLA-4 Nb16 induced $\mathrm{CD}^{+} \mathrm{T}$ cell activity with stronger cytotoxicity and anti-tumor effects against HepG2 cells for adoptive immunotherapy. ${ }^{76} \mathrm{CXCR} 4$ is the receptor of chemokine CXCL12, and CXCL12 is likewise understood as stromal cell-derived factor-1 (SDF-1) ${ }^{77}$ CXCR4 $\mathrm{Nb}$ can block the formulation of CXCR4/CXCL12 axis, ${ }^{78}$ thus imposing restrictions on the propagation of cancer cells; ${ }^{79,80}$ Endothelial glycoprotein endoglin (CD105) $\mathrm{Nb}$ restricts endoglin-mediated signal transduction pathway and has an anti-proliferative effect on neovascular endothelial cells in tumor and neovascularization; ${ }^{81,82}$ Heterogeneous nuclear ribonucleoprotein $\mathrm{K}$ (hnRNP K) $\mathrm{Nb}$ inhibits the invasion and metastasis of tumor cells by controlling the expression of genes related to tumor progression; ${ }^{83-85}$ CapG $\mathrm{Nb}$ can control G-actin aggregation and strongly inhibit breast cancer metastasis; ${ }^{71}$ The novel, orally administered anti-TNF agent, nanobody V565, having achieved Phase II trials for treatment of Crohn's disease. ${ }^{86}$ The $\alpha 3 \beta 1$ integrin (VLA-3) $\mathrm{Nb}$ can inhibit VLA-3-connected cell-matrix adhesion. ${ }^{87}$ The 
increase of B cell-activating factor (BAFF) seemingly contribute to various $\mathrm{B}$ cell diseases. Anti-BAFF $\mathrm{Nb}$ can cut down extracorporeal cell proliferation in cancer tumors. ${ }^{88}$ Anti-BAFF/CD20 bispecific $\mathrm{Nb}$ can improve the tissue targeting of B-cell disease and change the drug resistance of patients with chronic lymphoblastic leukemia (CLL) to CD20 antibody therapy. ${ }^{89} \mathrm{CD} 38$, as a cell surface antigen, can heavily be expressed in a number of hematological diseases, including multiple myeloma, and it has been verified to be a conducive target for immunotherapy strategy against this disease. ${ }^{90} \mathrm{~A}$ few $\mathrm{Nb}$ can influence CD38 activity in a dose-dependent mode and specifically target tumor cell CD38 in mouse xenotransplantation model. ${ }^{91,92}$ Because of its high solubility, $\mathrm{Nb}$ can form chimeric antibodies with hinge, $\mathrm{CH} 2$ and $\mathrm{CH} 3$ domains of human IgG1, this chimeric antibody can induce classical Fc-mediated cytotoxicity. ${ }^{93}$ Although $\mathrm{Nb}$ has made much exciting progress in the tumor therapy side, the pharmacokinetics, targeting effect and immunogenicity of $\mathrm{Nb}$ drugs undergo further optimization.

\section{Nanobody as Targeting Ligand for Tumor Drug Delivery}

In the design of the targeted nano-drug delivery system, the antibody-drug conjugates (ADCs) coupled with the surface of nanoparticles (NPs) or conjugated directly with drug molecules can achieve the targeted delivery of traditional anticancer drugs. ${ }^{94}$ ADCs are rather a concept of targeted drug design that has attracted much attention in clinical practice. Compared with small-molecule ligands such as folic acid and RGD (Arg-Gly-Asp) tripeptides, the most prominent advantage of antibodies is the excellent targeting performance of antibody-antigen binding. ${ }^{95,96}$ Since Trasmzumab was used in the treatment of HER $2^{+}$ breast cancer in 1998, the development of mAb antibody drugs targeting the EGFR family has been gaining momentum. ${ }^{97}$ The huge advantages in tumor clinical treatment, such as reducing toxic and side effects and overcoming multidrug resistance, make the research and application of antibody drugs in clinical treatment have a great prospect. ${ }^{98,99} \mathrm{Nb}$, a star molecule, is expected to replace $\mathrm{mAb}$ and becomes a feasible strategy to improve the effectiveness of nanomaterials-based cancer diagnosis and therapy. As early as 2004, Cortez-Retamozo and her team fused $\mathrm{Nb}$ targeting human tumor-associated embryogenesis with Enterobacter Cloacae $\beta$-lactamase in the form of fusion expression to prepare nanobody conjugations which had better target ability in animal model experiments and has the obvious effect of decreasing tumor size and even curing the animals. ${ }^{53}$

Traditional small molecule anticancer drugs are often limited in clinical application due to side effects and drug resistance. The concept of nanodrug delivery system (nanoDDS) reflected the new design philosophy for drug delivery methods. ${ }^{100}$ Embedding small-molecule chemotherapeutics with nanoscale drug carriers can not only solve the problem of hydrophobic drug solubility, the problem of easy removal of drugs in the blood circulation process, and the accumulation of difficult drugs in the treatment target. ${ }^{101}$ In addition, it is also possible to prepare an integrated diagnosis and treatment system, a multidrug co-transport system, chemotherapy combined with light and hyperthermia, or a combined system of chemotherapy with other means of complex system. ${ }^{102}$ The multifunctional DNA-based nano platinum-drug delivery system provided a promising strategy for the treatment of tumors, an anti-EGFR $\mathrm{Nb}$ was conjugated to DNA and assembled on to double-bundle DNA tetrahedron, which presented the first example of DNA intercalator and EGFR blockade. ${ }^{103}$ By modifying nanoDDS with targeted functions of ligands, the enrichment of nanomedicine in tumor tissues can be enhanced so as to improve the distribution of drug system in vivo and increase the specific uptake of nanoDDS by tumor cells. ${ }^{104,105}$ There are quite a few researches about modifying $\mathrm{Nb}$ on the outer layer of nanoparticles to enable nanoDDS actively targeted, ${ }^{106}$ such as liposomes, ${ }^{107}$ micelles, ${ }^{108}$ protein nanostructures, ${ }^{109}$ inorganic nanoparticles, ${ }^{110}$ polymer composites, ${ }^{111}$ etc.

Although $\mathrm{Nb}$ has no Fc effector and does not produce cytotoxic effects such as ADCC like traditional antibodies, it can be used as a targeting moiety on liposomes or nanoparticles encapsulating cytotoxic drugs to enhance the killing effect of tumor because of its high specificity and strong tissue penetration in Figure 4. ${ }^{112,113}$ For example, VEGFR2 Nb-associated Pseudomonas aeruginosa exotoxin has a better anti-tumor effect, ${ }^{114}$ and DM1, a microtubule polymerization inhibitor associated with major histocompatibility complex-II (MHC-II) $\mathrm{Nb}$, also has a good therapeutic effect. ${ }^{94}$ The formation and mechanism of nanobody-drug conjugates for targeting tumor cell with overexpressing EGFR is systematically elucidated in Figure 5 and the nanobody-based platform for targeted treatment system has been developed. ${ }^{115}$ Neural stem cells (NSC) were transfected with recombinant proteins encoding bivalent anti-EGFR $\mathrm{Nb}$ and 


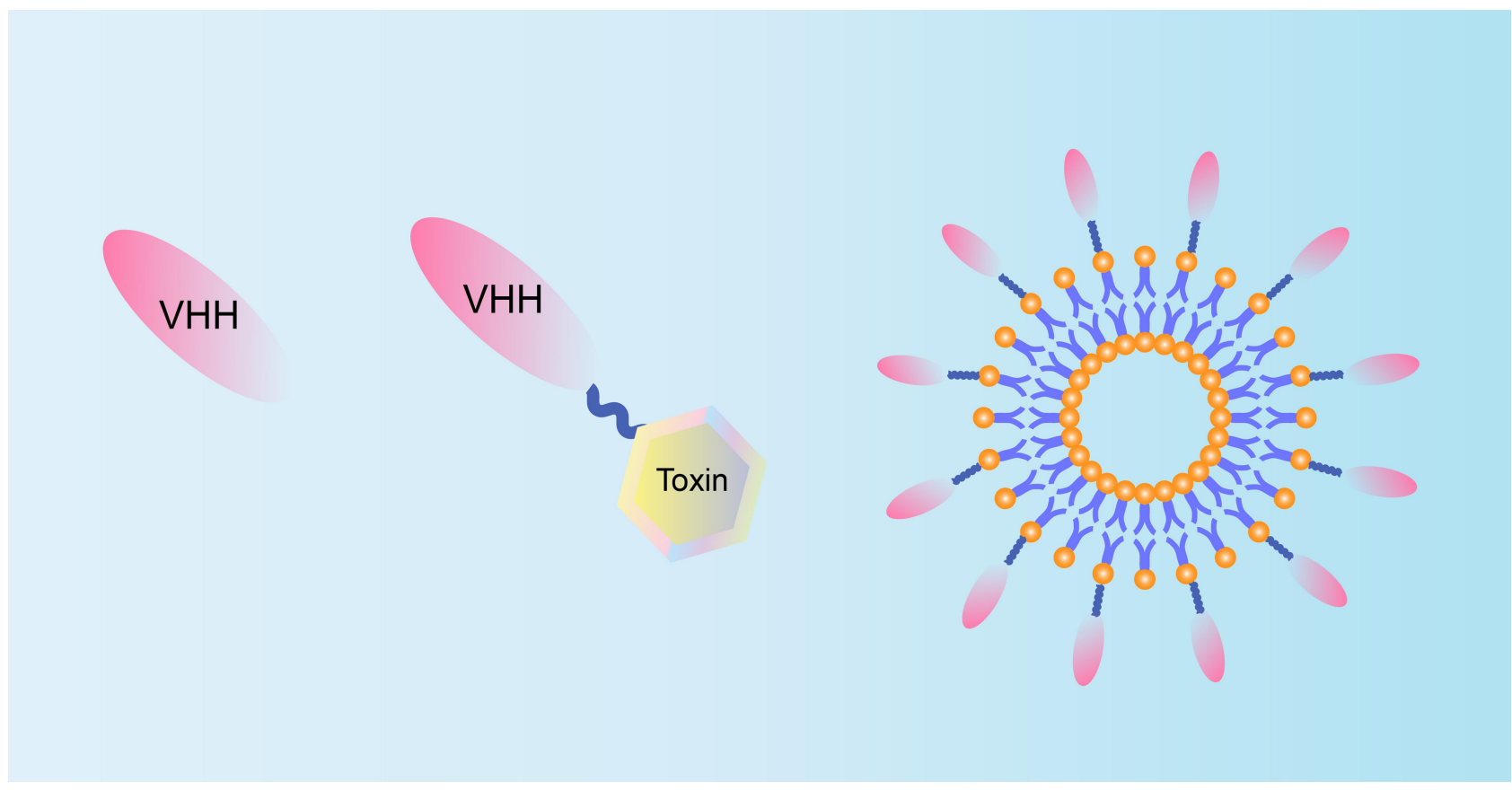

Figure 4 Diagrammatic sketch of nanobody-based therapeutic drug design. Left: Receptor antagonists, interfere with signal transduction and receptor activation; Middle: Targeting part of effector domain, such as medicine or toxic peptides; Right: Targeting molecules on the surface of nanoparticles, such as micelles or liposomes. Adapted from Bannas P, Hambach J, Koch-Nolte F. Nanobodies and Nanobody-Based Human Heavy Chain Antibodies As Antitumor Therapeutics. Front Immunol. 20I7;8:1603. Creative Commons license and disclaimer available from: http://creativecommons.org/licenses/by/4.0/legalcode. ${ }^{20}$

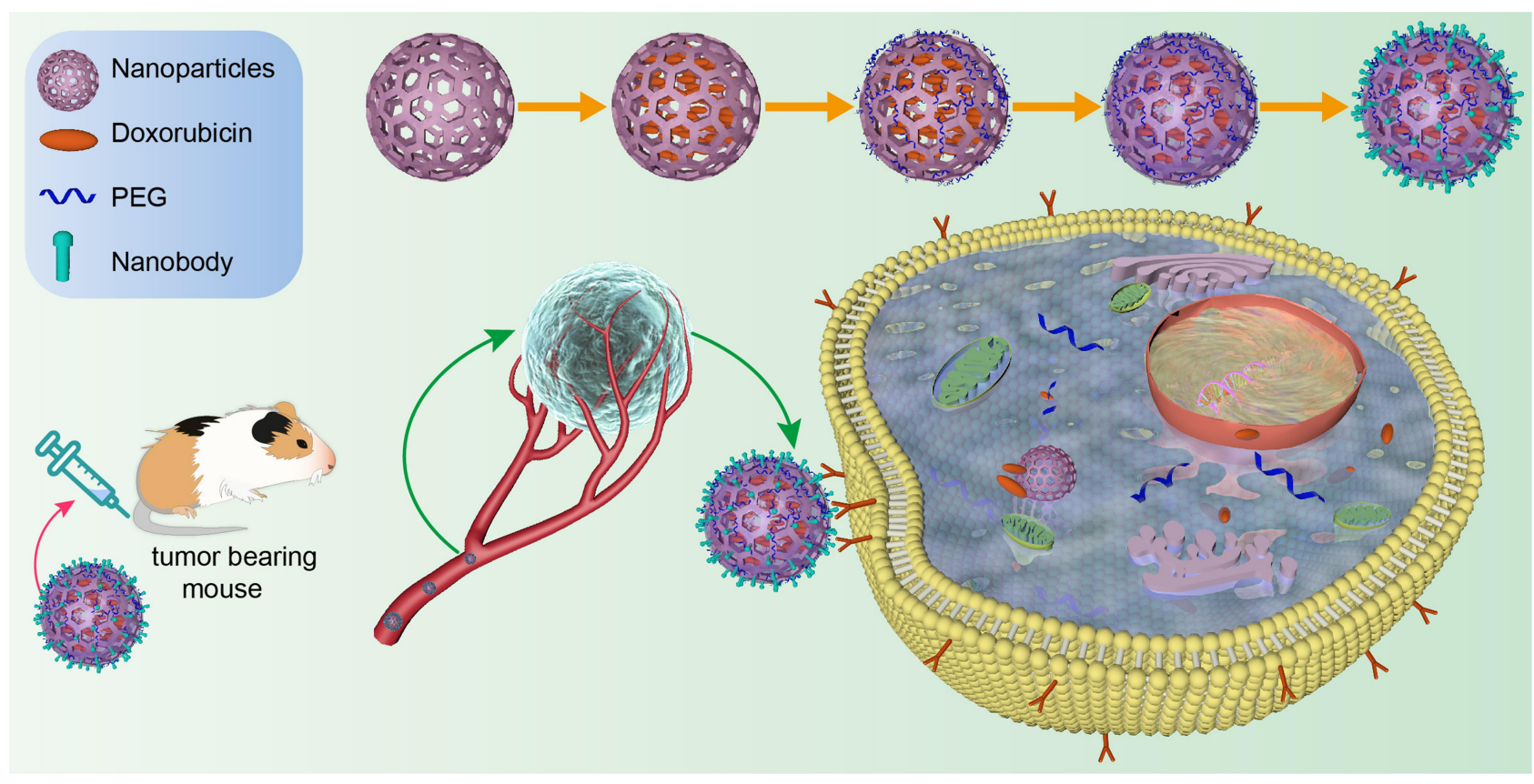

Figure 5 Schematic illustration of the construction and mechanism of nanobody-drug conjugates for targeting tumor cell. Nanobody targeting intracellular tumor marker to inhibit growth and proliferation after intravenous injection of tumor-bearing mouse: effective accumulation in tumor tissues; penetrating into tumor parenchyma; and internalized into cancer cells to produce combined chemotherapy and immunotherapy. Adapted with permission from Wang F, Zhang L, Bai X, et al. Stimuli-Responsive Nanocarrier for Co-delivery of MiR-3I and Doxorubicin To Suppress High MtEF4 Cancer. ACS Appl Mater Interfaces. 20I8;10(26):22767-22775. Copyright (20I8) American Chemical Society. ${ }^{197}$ 
cytotoxic TRAIL, which significantly reduced the viability of malignant glioma cells. ${ }^{116}$ A HER2-specific $\mathrm{Nb}$ comes complete with a molecule that can recruit antidinitrophenyl antibodies that can cause tumor cell destruction. ${ }^{117}$ Polymeric nanoparticles can serve as a vehicle for the delivery of cytotoxic proteins that have intracellular targets, that selective uptake can be attained by decorating the surface of the NPs with the 11A4 nanobody that is specific for the HER2 receptor. ${ }^{118}$ The flexible nanobody-based system can be adapted to load pentamidine, and designed with components based on polyethylene glycol (PEG) and were conjugated with a nanobody that specifically recognizes the protozoan pathogen Trypanosoma brucei. ${ }^{119}$ Simone and his group have pioneered the application of elastin-like polypeptides (ELPs) as the same category of peptide polymers that selfassembly into nanoparticles for drug delivery to optimize the ligand-nanoparticle interface to enhance cancer cell targeting by polymer micelles. ${ }^{120}$ In the antibody-directed enzyme-catalyzed prodrug therapy (ADEPT) experiment, it was found that the $\mathrm{Nb}$ of anti-CEA delivered the coupled $\beta$-lactamases to the surface of $\mathrm{CEA}^{+}$tumor cells, activating the anticancer prodrug cephalosporin nitrogen mustard, thus improving the selectivity of anticancer drugs to tumor cells. ${ }^{53}$ The relevant experimental results showed that the EGFR-Rapa-NPs system modified with EGFR antibody had a better tumor inhibition effect than the drug delivery particles without antibody conjunction, and at the same time had significant cellular selectivity. ${ }^{121}$ The $\mathrm{Nb}$ of the target EGFR was acylated by biotin and coupled with the colloidal particles coated with streptavidin, which could directly target $\mathrm{EGFR}^{+}$liver tumor cells. ${ }^{122}$ Targeting plexinD1 (a membrane-penetrating protein expressed in tumor vessels) Nb-modified tumor vascular targeted polymerase represented a promising approach in treating divergent carcinomatosis. ${ }^{104,123}$

Therefore, $\mathrm{Nb}$ can play an important role as a drug delivery system. The sealed drugs can be delivered to the action site by using the specificity of mass production of versatile nanobody repertoires. ${ }^{124,125}$ The Belgian pharmaceutical firm Ablynx stepped into standard nanobody therapy which was tiny enough in volume that can be ingested, whereas the traditional antibody drug was given by injection to enter the bloodstream. ${ }^{126}$ This method can avoid the systemic toxicity caused by common drug administration, and allow hydrophobic drugs to be transported in hydrophilic structures. In addition, large doses of drugs can be administered in this way, these drug delivery systems incorporated into $\mathrm{Nb}$ can protect drugs against oxidereduction and enzymatic reactions, so as to avoid the immunogenicity produced by multiple administration. ${ }^{127-129}$ Coupled with the effect of other drugs and $\mathrm{Nb}$ itself can inhibit tumor growth, which is equivalent to the dual function of $\mathrm{Nb}$.

\section{Nanobody in Combination with Other Tumor Therapies} Nanobody Combining with Radioimmune Therapy (RIT)

At present, the main radionuclides used in clinic are $\beta$ decay nuclides, including ${ }^{90} \mathrm{Y},{ }^{131} \mathrm{I}$ and ${ }^{177} \mathrm{Lu}$, but some $\alpha$ decay nuclides have been used. ${ }^{130}$ The radionuclide labeled anti-CD20 monoclonal antibody $\left({ }^{90}\right.$ Y-ibritumomab tiuxe$\tan$ ) approved by FDA has been put on the market, ${ }^{131}$ and 44 kinds of these drugs in the treatment of solid tumors and hematological malignant tumors are in clinical trials. ${ }^{132,133}$ When common radiopharmaceuticals are used in RIT, while the advantage of long half-life brings bad pharmacokinetic characteristics to radionuclides and poor permeability to tumors, which limits their targeting effect. By comparison, the radiolabeled $\mathrm{Nb}$ is more targeted and can be quickly removed from the blood. ${ }^{134}{ }^{177} \mathrm{Lu}$-labeled targeted $\mathrm{M}$ protein ( $\mathrm{M}$ protein is a monoclonal antibody produced by malignant plasma cells) $\mathrm{Nb}$ is being used in the treatment of multiple myeloma in order to inhibit the progression of the disease. ${ }^{135}$ The 2 Rs $15 \mathrm{~d}$ of ${ }^{177} \mathrm{Lu}$ labeled targeted HER2 was prepared. The metal binding region of the bifunctional joint 1B4MDTPA was connected with radionuclides and the chemically active region was connected with $\mathrm{Nb} .{ }^{136} \mathrm{In}$ order to avoid radiation damage caused by the accumulation of $\mathrm{Nb}$ in renal tissue, co-administration with plasma expander succinyl gelatin (Gelofusin) could almost completely block the growth of tumor in HER $2^{+}$ tumor-bearing mice. There was critical variation among event-free survival (EFS) between the treated group and the non-treated group. ${ }^{137}$

\section{Nanobody Combining with Photodynamic Therapy (PDT)}

In contrast to radionuclides in RIT, PDT can damage irreparably tumor cells via motivating photosensitizer (PS). ${ }^{138}$ On the basis of PDT preponderance for precise treatment and slight side effect, ${ }^{139}$ currently at the forefront of research, PS takes on a shape of treelike gold nanoparticles (branched gold NP), because of its huge 
absorption cross section, NP will destroy tumor cells through heat production after laser irradiation. ${ }^{140}$ The junction which might selectively accumulate in vivo between Anti-HER2 nanobody and PS can give rise to striking inhibitory effect on especially against trastuzumab $\mathrm{HER}^{+}{ }^{+}$breast carcinoma with a single course of therapy, the tumor extinction was positive dose dependent, which will greatly enhance specifical targeting for photothermal anticancer agents. ${ }^{141}$ The combination of molecular imaging and tumor therapy in the connection application of Anti-EGFR univalent or multivalent $\mathrm{Nb}$ and traceable PS (IRDye-700DX) is major progress in the clinical application of PDT technology. ${ }^{142}$

\section{Nanobody-Modified CAR-T Therapy}

$\mathrm{Nb}$ can be more than just steering anti-tumor function, medicine carrier system or radionuclide treatment, but act an adjustive character on macrophages which have long been considered to be important immune effector cells. ${ }^{143}$ Cytokines are molecules which possess broad development prospect to be used in anti-tumor immune treatment on account of irritating the natural killer cells of both innate and acquired immunity. ${ }^{144,145}$ According to the theory that FcyRIIIa (CD16a) on immune effector cells can mediate cytotoxicity, two $\mathrm{Nb}$ (C21 and C28) specifically binding to FcyRIIIa isolated from camel immune library indirectly mediate the ADCC effect of NK cells. ${ }^{146}$ If the $\mathrm{Nb}$ is linked to anti-CEA Nb, it can dissolve $\mathrm{CEA}^{+}$tumor cells through NK cells in vitro models of human cells and tissues, and also suppress cancer cell growth in $\mathrm{CEA}^{+}$tumor transplanted mice, which fosters new thinking on the development of anti-tumor $\mathrm{Nb}^{147}$

There was too much of a correlation between immune infiltration and tumor microenvironment (TME), which has turned out to be enormously successful in clinical cancer immunotherapeutic. ${ }^{148,149}$ CAR-T cell therapy is one of the research hotspots of tumor immunotherapy and has a good prospect for the treatment of hematological tumors, which makes patients' own $\mathrm{T}$ cells genetically modified to better attack cancer cells (Figure 6B). ${ }^{150,151,195}$ Compared with traditional antibodies, $\mathrm{Nb}$ has more advantages in the process of constructing CAR$\mathrm{T}$ cell. ${ }^{152}$ At present, the binding sites of antigens recognized in CAR are mostly designed based on the $\mathrm{scFv}$ (Figure 6A), which has high immunogenicity. $\mathrm{Nb}$ can reduce this kind of immunogenicity. ${ }^{153}$ CAR-T cells obtained by using $\mathrm{Nb}$ as a connecting or targeting part is also one of the effective ways to avoid tumor escape. At the same time, it was found that Nb-based CAR-T could fully exert its advantages of T cell immunotherapy, such as resultful tumor invasion and metastasis, induced the release of inflammatory cytokines and cytotoxic action. On the $\mathrm{Nb}$ treatment side, which also has relative comparative advantages in small size, decreased immunogenicity and strong specificity of related tumor antigens. ${ }^{154}$ For instance, CAR targeting melanocyte differentiation antigen gp100 $\mathrm{Nb}$ can inhibit the development of melanoma in vivo. ${ }^{155}$

However, CAR-T cells are not good at treating solid tumors because it is difficult to find tumor-specific proteins that can be used as safe targets in solid carcinoma. ${ }^{156}$ Given the current situation that CAR-T cell treatment has yet to be extrapolated to solid malignancies, researchers plan to solve this problem according to the characteristics of $\mathrm{Nb}$, which can advance CAR-T cell technology for therapy of carcinoma. ${ }^{149}$ One of the unique properties of $\mathrm{Nb}$ is its enhanced targeting ability to carry imaging agents so that metastatic tumors can be visualized accurately. Jailkhani and his team directed these $\mathrm{Nb}$ to the tumor extracellular matrix (ECM) or as targeted imaging agents for ECM, mainly targeting the tumor microenvironment that surrounds cancer cells. ${ }^{157}$ The CAR-T cells constructed by some investigators are embedded with $\mathrm{Nb}$, to recognize specific proteins in the tumor microenvironment, and Nbs usually carry signals that guide them to kill the cells they can bind to. ${ }^{158,159}$ For example, a protein called EIIIB is a variant of fibronectin and is found only in neovascularization that provides nutrients for tumors. ${ }^{160}$ The other is PD-L1, an immunosuppressive protein that is used by most tumors to silence neighboring T cells. ${ }^{161}$ Use these relatively specific antigens to prepare $\mathrm{Nb}$-based CAR-T cells. By testing in two different melanoma mouse models, these cells can kill tumor cells and significantly improved the survival of these mice without distinct side effects. Targeting EIIIB may damage blood vessels in a way that reduces the tumor's blood supply while making them more permeable to tumor drugs. The preliminary results show that the method may achieve ideal results for many solid tumors, such as pancreatic cancer and cholangiocarcinoma models. ${ }^{149}$

Although CAR-T can effectively induce $T$ cells to attack tumor cells, it can also produce side effects such as cytokine storm syndrome. ${ }^{162}$ In order to further reduce this side effect and improve the curative effect, some researchers developed a $\mathrm{T}$ cell antigen coupling agent, which can couple the chimeric antigen of endogenous 

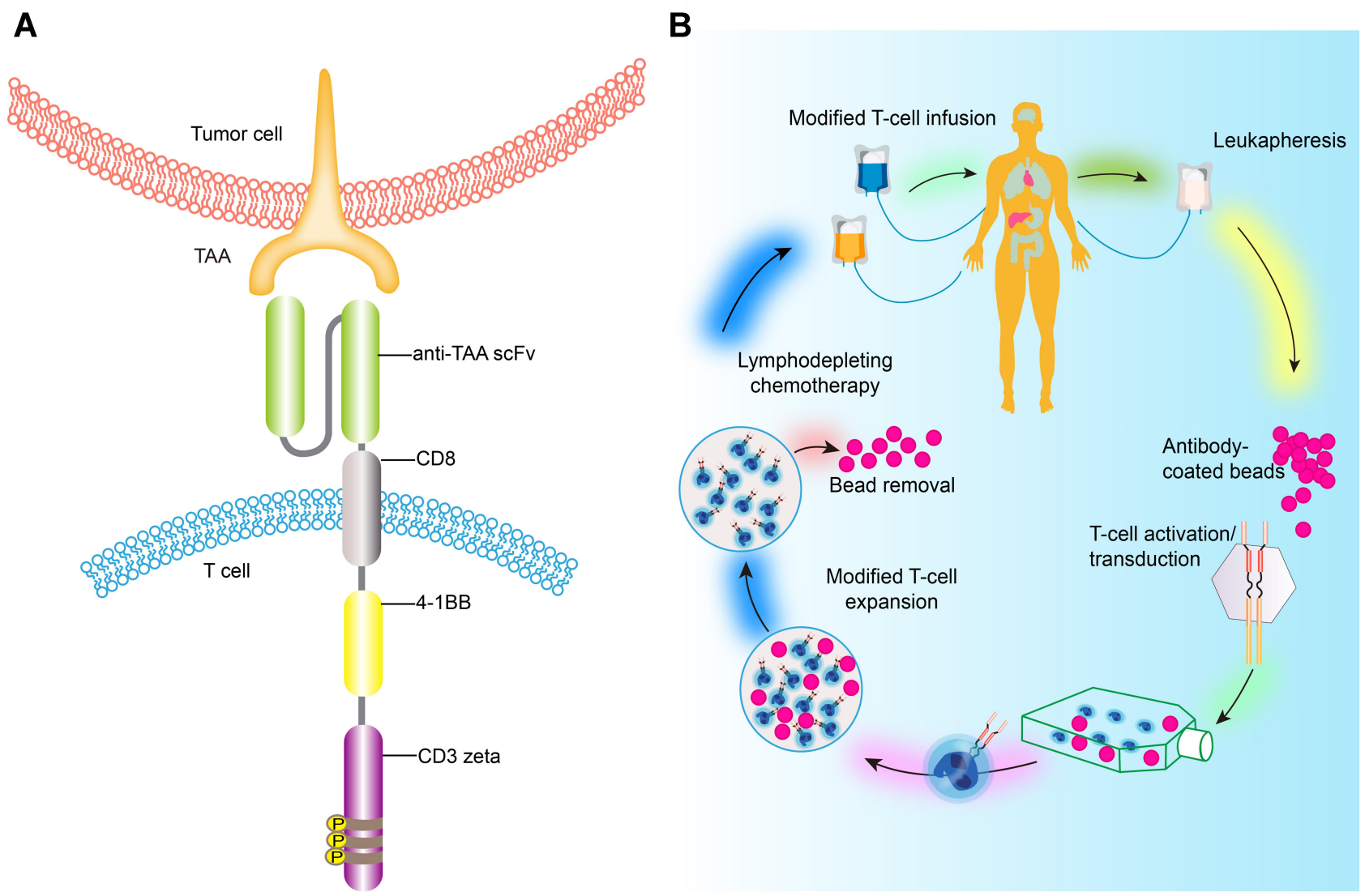

Figure $6 \mathrm{~A}$ brief flow chart of engineered-T cell therapy. (A) represents the CAR, which includes the single-chain variable fragment (scFv) that binds to tumor antigens, fused to a spacer and transmembrane domain. The intracellular domain contains costimulatory domains, such as CD28 and 4-IBB and the CD3 $\zeta$ chain, which cause signal activation and amplification of CAR T cells. S-S denotes disulfide bond. Adapted from Tyagarajan S, Spencer, Smith J. Optimizing CAR-T Cell Manufacturing Processes during Pivotal Clinical Trials. MOI Ther Methods Clin Dev. 2020;16:136-I44. Creative Commons license and disclaimer available from: http://creativecommons.org/licenses/by/4.0/ legalcode. ${ }^{194}$ (B) shows a process of CAR-T therapy, firstly apply the patient's own T lymphocytes, which have been reconstructed in the laboratory and loaded with $\overline{\text { receptors }}$ and co-stimulating molecules that recognize tumor antigens. After amplification in vitro, they are re-introduced to the patient to recognize and attack their own tumor cells. Adapted from Tyagarajan S, Spencer, Smith J. Optimizing CAR-T Cell Manufacturing Processes during Pivotal Clinical Trials. MOI Ther Methods Clin Dev. 2020;16:136-144. Creative Commons license and disclaimer available from: http://creativecommons.org/licenses/by/4.0/legalcode. ${ }^{194}$

TCR, namely chimeric TAC-T ( $\mathrm{T}$ cell antigen coupler-T cell). ${ }^{163}$ It mainly includes the design of three key parts: one is that the extracellular antigen binding domain is changed into $\mathrm{Nb}$, the second part is extracellular antiCD3 scFv, and the third part is the membrane-penetrating CD4 domain connecting protein kinase LCK. TAC-T represents a significant advance in CAR-T and TCR-T therapies because TAC is able to identify tumor cells more selectively, utilize natural activation and regulatory mechanisms to activate $\mathrm{T}$ cells through natural TCR, and lack tonic signaling, so that $\mathrm{T}$ memory cells persist (instead of being depleted). ${ }^{164,165}$ Thus, TAC engineered $\mathrm{T}$ cells can reasonably hope to facilitate a treatable tumorspecific reaction that reduces toxicity and eliminates solid tumors. ${ }^{166}$ In the solid tumor model, TAC-T cells showed stronger anti-tumor effect, lower cytotoxic side effects, faster tumor penetration and higher therapeutic index than CAR-T cells activated by the second signal based on CD28. According to the efficacy of TAC-T cells and the biological characteristics of $\mathrm{Nb}$, TAC-T-like cells based on $\mathrm{Nb}$ may also produce more ideal therapeutic effects. $^{167}$

\section{Challenges and Prospects in Nanobody-Related Tumor Therapy}

Antibodies have been used more than decades for ectophylaxination to treat infected patients. While polyclonal antibodies produce superior neutralization and thus better protection under normal circumstances, monoclonal $\mathrm{Nb}$ selected for recognition of special epitopes might reach an exceedingly high-neutralization potency. ${ }^{168}$ Although the current research results show that $\mathrm{Nb}$ has great potential 
in tumor treatment, ${ }^{169}$ the application of $\mathrm{Nb}$ still has some weaknesses: (1) The immunized animals such as camels are relatively expensive compared with the frequently used mice for the production of antibody. ${ }^{113}$ (2) Their small dimension is also a disadvantage in cancer treatment as they are rapidly eliminated from the blood via individual kidney glomerular filtration, hence a small proportion of the total Nbs aggregate at the site of action, which might be settled by administration of standard and high dose regimens. ${ }^{170}$ (3) The negative impact that $\mathrm{Nb}$ will not biodegrade immediately when they are released into the environment due to it yields higher stability, ${ }^{171}$ therefore the risks of $\mathrm{Nb}$ need to be evaluated due to antibiotics release in groundwater can destruct agriculture. ${ }^{172}$

On account of nanobodies connect the salutary properties of micromolecule and monoclonal antibodies, an attractive agent for new therapeutic strategies is likely to emerge. Until now, biomedical engineering is turning into a level of subcellular, which is advanced with a rapid-developing field of research on nano diagnostics, nanomedicine and nano therapy in joint with the success of nanoparticles on sickness prevention and health promotion. $^{173}$ Cancer treatment has hit a bottleneck, tumor cells proliferate in complicated tumor microenvironments, thus causing heterogeneous diseases, usually with a fatal outcome in later stages for the patient. Therefore, nanobody emerges as the times require. Nanobody is a new and unparalleled class of multiple antigen-binding fragments, which originated from heavy-chain antibodies extracted from the serum of camelids naturally. Their favorable characteristics like small size, strong consistency, top antigen-binding affinity, natural formation and water-soluble material might generate the next cancer drug. Consequently, $\mathrm{Nb}$ has extraordinary potential in cancer care and control, and is anticipated to make a significant breakthrough technology in immunotherapy field. Their small volume acquires them conducive to target antigens residing in different tissues that are impotently vascularized and barely accessible.

The infiltration and growth of certain types of solid tumors typically hinge on the generation of new blood vessels and acceleration of their maturation and stabilization. Previous studies have shown that a few nanobodies take part in impacting this phenomenon of vascularization. ${ }^{174} \mathrm{Up}$ to now, potential targets applied to nanobody-based therapies are extracellular targets. For instance, ligand receptors or transmembrane proteins with differential expression in major target cells. For this purpose, nanobodies against transmembrane growth factor receptors EGFR, VEGFR-2, c-Met and chemokine receptor type 7 (CXCR7) have been developed. ${ }^{175-179}$ those receptors have been related to cancerous growths. Moreover, in oncologic therapeutic areas understanding the molecular biology of the disease increases; thus, the chances of developing specific targeted drugs increase. So nanobodies can be used either as antagonists, to prevent ligand binding and causing conformational changes that lead to activation of signaling cascades for the cancer therapy, their superior properties (small size, high antigenbinding affinity, low immunogenicity, high stability and solubility) allowed for several groups to conduct clinical trials. $^{180-182}$

Based on the fact that nanobodies can bind to each protein and enzyme to form a combination with dual functions, the inactive prodrugs can be transformed into active drugs that can kill cancer cells, so as to focus on targeted chemotherapy of tumor cells, to achieve high efficiency and without any adverse reactions. It is envisaged that the construction of nanobodies and molecular drugs for the treatment of cancer will make use of the targeting and good tissue permeability of nanobodies. It will make antineoplastic drugs cease a more directly effective function especially in imaging and radionuclide therapy. $^{183}$

The construction of multi-target nanocomposite antibody or multi-target combination of drugs will bring a new perspective to the treatment strategy of malignant diseases and play a better curative effect. With the indepth study of biochemistry and human genomics and the exploration and development of nanobodies, an increase number of therapeutic targets for cancer will be found. Recently a shuttling-nanobody FC5 that targets immunological access linked to neuroinflammation for drug delivery technique of breaking brain barrier has been developed. ${ }^{184}$ According to this, an ideal nanomedicine might have the following characteristics, which include tumor accumulation, deep penetration, long circulation, cellular internalization, and drug release for highly efficient tumor-associated therapeutic strategies (Figure 7). In the context of the global outbreak of COVID-19 pandemic and urgent demand of pressing development for effective prophylactics or therapeutics especially for immunocompromised patients. LQ050, the world's first inhaled COVID-19 neutralizing nanobody drug, due to its excellent stability profile, and superior nebulization, 


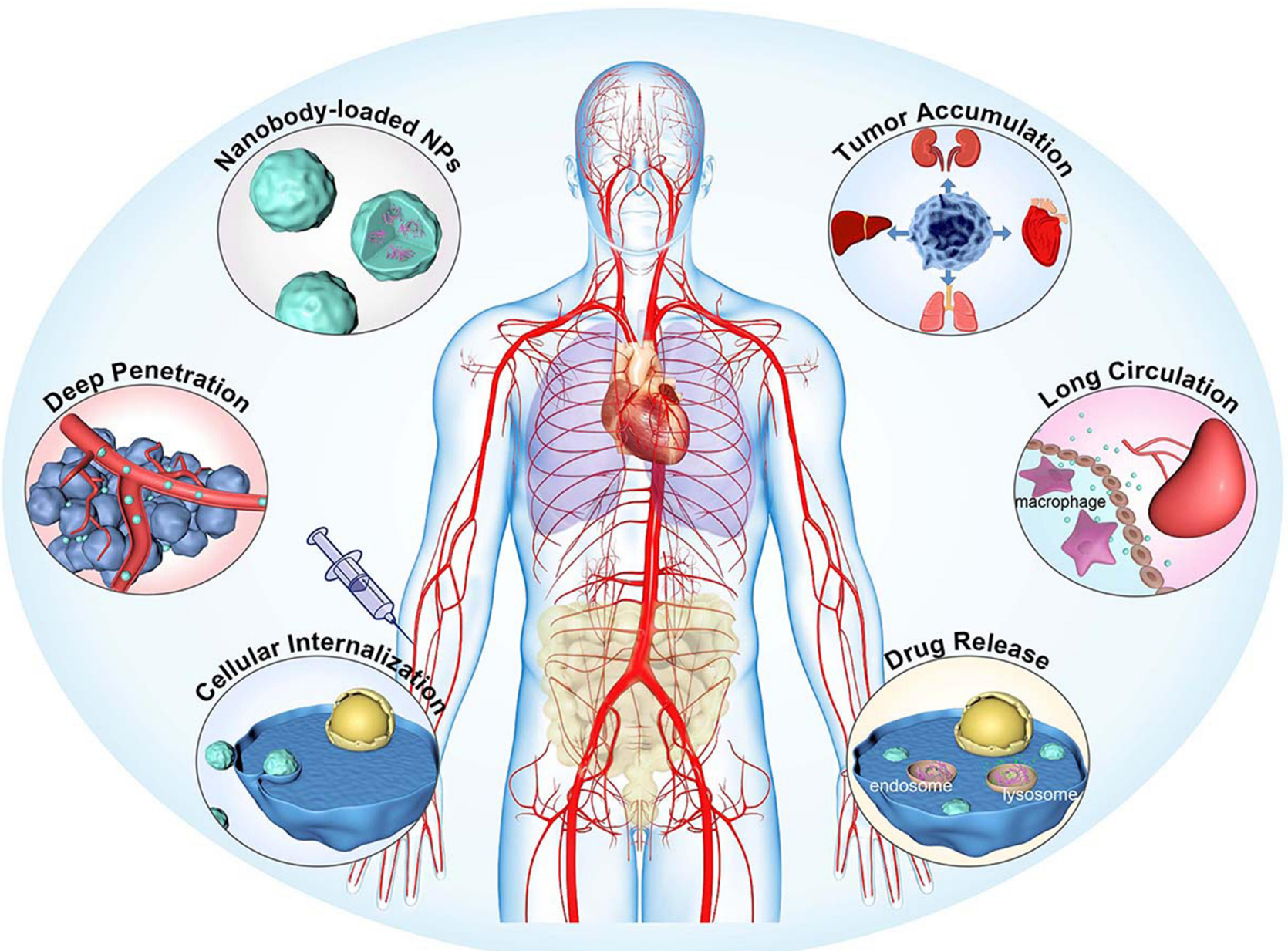

Figure 7 Nanoparticles as antitumor Drugs. The overall therapeutic efficiency of a nanobody-based compound medicine is determined by its efficiency in each step. During the transportation of blood lumen and tumor tissue, it must hold the drug tightly without burst release, and synchronously release the drug until at the intracellular site to exert its pharmaceutical action. Adapted with permission of Royal Society of Chemistry, Chem Soc Rev, from Influence of nanomedicine mechanical properties on tumor targeting delivery. Li Z, Xiao C, Yong T, Li Z, Gan L, Yang X. 49(8):2273-2290, copyright 2020; permission conveyed through Copyright Clearance Center, Inc. ${ }^{198}$

might be the first nanobody drug against SARS-COV with the delivery manner of respiratory drug. ${ }^{185}$ As a result, the targeted therapy of nanobodies for tumor treatment has entered a new era.

The optimization of phage display technology will promote the construction of $\mathrm{Nb}$ library and the screening of specific $\mathrm{Nb}$. The improvement of humanized $\mathrm{Nb}$ will further reduce the immunogenicity of $\mathrm{Nb}$ and improve the safety and effectiveness. Its strong tissue penetration will facilitate the intervention and treatment of solid tumors, especially the local microenvironment. ${ }^{186}$ Nano-carriers carrying radionuclides, toxins or chemotherapeutic drugs will provide more treatments for tumor patients. CAR-T or TAC-T based on $\mathrm{Nb}$ will become the replacement of traditional CAR-T. The nanobody platform is now a main focus for immunooncology discovery research for pharmaceuticals giant and nanobody is now being tested in a series of clinical trials which are shown in Table $1 .{ }^{187}$ In a word, $\mathrm{Nb}$ will achieve a breakthrough in replacing traditional targeted antibody drugs, ADC drugs, fusion proteins, local tumor intervention therapy and oral antibody therapy.

\section{Conclusion}

To summarize, nanobodies are versatile molecules with favorable properties and have been evaluated for both therapeutic and diagnostic applications, as well as research tools. Nanobodies are featured by their small size, increased solubility as well as desirable stability opening up the gate towards previously inaccessible antigens in cancer immunotherapy. These tiny antibodies outperform conventional antibodies in quite a few respects and thrive in extreme conditions, ultimately, they will occupy a momentous portion of the antibody reagent market. After the initial research on functional heavy chain antibodies in alpaca, the versatility of antigen-binding 
Table I Nanobody in Clinical Trials

\begin{tabular}{|c|c|c|c|c|}
\hline Molecule & Target & Disease Examples & $\begin{array}{l}\text { Current } \\
\text { Status }\end{array}$ & $\begin{array}{l}\text { References } \\
\text { Sponsor }\end{array}$ \\
\hline Caplacizumab (ALX-008I) & Von Willebrand factor & $\begin{array}{l}\text { Acquired thrombotic } \\
\text { thrombocytopenic purpura }\end{array}$ & Approved & {$[182,188]$} \\
\hline Ozoralizumab (ATN-I03) & TNF- $\alpha$ & Rheumatoid arthritis & Phase 2 & Ablynx \\
\hline MI095(ALX-076I) & IL-I7A, IL-I7F & Psoriasis & Phase I & [189] \\
\hline Vobarilizumab (ALX-006I) & IL-6R & $\begin{array}{l}\text { Rheumatoid arthritis, systemic lupus } \\
\text { erythematosus }\end{array}$ & Phase 2 & {$[190]$} \\
\hline$A L X-0141$ & RANK ligand & Osteoporosis, bone metastasis & Phase I & Ablynx \\
\hline $\begin{array}{l}\text { BCMA nanobody CAR-T } \\
\text { cells }\end{array}$ & BCMA & Relapsed/Refractory Myeloma & Phase I & $\begin{array}{l}\text { Yongping } \\
\text { Song }\end{array}$ \\
\hline aPDI-MSLN-CAR T cells & MSLN & $\begin{array}{l}\text { Non-small-cell Lung Cancer, } \\
\text { mesothelioma, colorectal cancer, } \\
\text { ovarian cancer }\end{array}$ & $\begin{array}{l}\text { Early } \\
\text { Phase I }\end{array}$ & $\begin{array}{l}\text { Xiaorong } \\
\text { Dong }\end{array}$ \\
\hline M6495 & $\begin{array}{l}\text { A Disintegrin and Metalloproteinase With } \\
\text { Thrombospondin Motifs-5 (ADAMTS-5) }\end{array}$ & Osteoarthritis, Knee & Phase I & {$[191]$} \\
\hline $\begin{array}{l}\text { CD20/HER2 Bispecific } \\
\text { Nanobody-derived CAR-T } \\
\text { Cells }\end{array}$ & CD20, HER2 & B cell leukemias, lymphomas & Preclinical & {$[192]$} \\
\hline ALX-065I & CXCR4 & Healthy Volunteers & Phase I & Ablynx \\
\hline$A L X-0|7|$ & RSV F-protein & RSV Infection & Phase 2 & [193] \\
\hline
\end{tabular}

Notes: Ablynx, Clinicaltrials.gov, PubMed, FDA.

Abbreviations: TNF, tumor necrosis factor; IL, interleukin; RANK, receptor activator for nuclear factor- $\kappa$ B; BCMA, B cell maturation antigen; MSLN, mesothelin; HER2, c-erbB-2; CXCR4, C-X-C motif chemokine receptor 4; RSV, respiratory syncytial virus.

proteins, strategies for their functionalization and methods for their cellular delivery lay a potent foundation for nextgeneration diagnostics and therapeutic tools with outstanding properties. The way is now open to further exploit the inexhaustible potential of nanobodies and to further position them as pharmaceuticals for use in daily clinical practice.

\section{Abbreviations}

$\mathrm{scFv}$, single-chain variable fragment; $\mathrm{Nb}$, nanobody; $\mathrm{sdAb}$, single domain antibody; $\mathrm{HcAb}$, heavy chain antibody; $\mathrm{CDR}$, complementarity determining region; $\mathrm{CH}$, constant domains of heavy chain; CL, constant domain of light chain; Fab, antigen-binding fragment; Fc, fragment crystallizable region; FR, frame region; $\mathrm{VH}$, variable domain of heavy chain; VHH, variable domain of heavy chain antibodies; VL, variable domain of light chain; ADCC, antibody-dependent cell-mediated cytotoxicity; CDC, complement-dependent cytotoxicity; EGFR, epidermal growth factor receptor; CEA, carcinoembryonic antigen; MUC1, Mucin 1; CAR-T cells, chimeric antigen receptor modified T cells; HIF-1 $\alpha$, hypoxia inducible factor-1 $\alpha$; ODD, oxygen-dependent domain; ANG2, angiopoietin 2; EspF, E. coli-secreted protein F; GPCRs, G protein-coupled receptors; CXCR4, chemokine receptor type 4; ACKR3, atypical chemokine receptor 3; HIV, human immunodeficiency virus; CTLA-4, cytotoxic T lymphocyte-associated antigen-4; SDF-1, stromal cell derived factor-1; CD105, endoglin; hnRNP K, heterogeneous nuclear ribonucleoprotein $\mathrm{K}$; VLA-3, $\alpha 3 \beta 1$ integrin; BAFF, B cell-activating factor; CLL, chronic lymphoblastic leukemia; ADCs, antibody-drug conjugates; NPs, nanoparticles; nanoDDS, nanodrug delivery system; MHC-II, major histocompatibility complex-II; NSC, neural stem cells; PEG, polyethylene glycol; ELPs, elastin-like polypeptides; ADEPT, antibodydirected enzyme-catalyzed prodrug therapy; RIT, radioimmune therapy; EFS, event-free survival; PDT, photodynamic therapy; PS, photosensitizer; TME, tumor microenvironment; ECM, extracellular matrix; TAC-T, T cell antigen coupler- $\mathrm{T}$ cell; CXCR7, chemokine receptor type 7; TNF, tumor necrosis factor; IL, interleukin; RANK, 
receptor activator for nuclear factor- $\kappa \mathrm{B}$; BCMA, B cell maturation antigen; MSLN, mesothelin; HER2, c-erbB-2; $\mathrm{RSV}$, respiratory syncytial virus.

\section{Ethics Approval and Consent to Participate}

This manuscript is a review article that does not require prior approval.

\section{Acknowledgments}

This work was supported, in part, by grants from Project of National Natural Scientific Foundation of China (No. 81773254); National Key Research and Development Plan "Inter-governmental Cooperation in International Scientific and Technological Innovation" (No. 2019YFE0117300); Guangxi Science and Technology Base and Talents Project (No. GuiKeAD20238062) and Guangxi Bagui Honor Scholars.

\section{Disclosure}

The authors declare that they have no conflicts of interest.

\section{References}

1. Kijanka M, Dorresteijn B, Oliveira S, van Bergen En Henegouwen PM. Nanobody-based cancer therapy of solid tumors. Nanomedicine (Lond). 2015;10(1):161-174. doi:10.2217/nnm.14.178

2. He T, Zhu J, Nie Y, et al. Nanobody technology for mycotoxin detection in the field of food safety: current status and prospects. Toxins (Basel). 2018;10(5). doi:10.3390/toxins10050180.

3. Hamers-Casterman C, Atarhouch T, Muyldermans S, et al. Naturally occurring antibodies devoid of light chains. Nature. 1993;363(6428):446-448. doi:10.1038/363446a0

4. Harmsen MM, Ruuls RC, Nijman IJ, Niewold TA, Frenken LG, de Geus B. Llama heavy-chain V regions consist of at least four distinct subfamilies revealing novel sequence features. Mol Immunol. 2000;37 (10):579-590. doi:10.1016/S0161-5890(00)00081-X

5. Li C, Tang Z, Hu Z, et al. Natural single-domain antibody-nanobody: a novel concept in the antibody field. J Biomed Nanotechnol. 2018;14 (1):1-19. doi:10.1166/jbn.2018.2463

6. Salvador JP, Vilaplana L, Marco MP. Nanobody: outstanding features for diagnostic and therapeutic applications. Anal Bioanal Chem. 2019;411(9):1703-1713. doi:10.1007/s00216-019-01633-4

7. Yu S, Xiong G, Zhao S, et al. Nanobodies targeting immune checkpoint molecules for tumor immunotherapy and immunoimaging (Review). Int J Mol Med. 2020;47(2):444 454. doi:10.3892/ ijmm.2020.4817

8. Wagner TR, Rothbauer U. Nanobodies right in the middle: intrabodies as toolbox to visualize and modulate antigens in the living cell. Biomolecules. 2020;10(12):1701. doi:10.3390/biom10121701

9. Verhaar ER, Woodham AW, Ploegh HL. Nanobodies in cancer. Semin Immunol. 2020;101425. doi:10.1016/j.smim.2020.101425

10. Bao G, Tang M, Zhao J, Zhu X. Nanobody: a promising toolkit for molecular imaging and disease therapy. EJNMMI Res. 2021;11(1):6. doi:10.1186/s13550-021-00750-5

11. Tanaka T, Lobato MN, Rabbitts TH. Single domain intracellular antibodies: a minimal fragment for direct in vivo selection of antigen-specific intrabodies. $J$ Mol Biol. 2003;331(5):11 09-1120. doi:10.1016/S0022-2836(03)00836-2
12. Streltsov V, Nuttall S. Do sharks have a new antibody lineage? Immunol Lett. 2005;97(1):159-160. doi:10.1016/j. imlet.2004.09.018

13. Skottrup PD. Structural insights into a high affinity nanobody: antigen complex by homology modelling. J Mol Graph Model. 2017;76:305-312. doi:10.1016/j.jmgm.2017.07.008

14. Fan K, Jiang B, Guan Z, et al. Fenobody: a ferritin-displayed nanobody with high apparent affinity and half-life extension. Anal Chem. 2018;90(9):5671-5677. doi:10.1021/acs.analchem.7b05 217

15. Khodabakhsh F, Behdani M, Rami A, Kazemi-Lomedasht F. Singledomain antibodies or nanobodies: a class of next-generation antibodies. Int Rev Immunol. 2018;37(6):316-322. doi:10.1080/ 08830185.2018.1526932

16. Dumoulin M, Conrath K, Van Meirhaeghe A, et al. Single-domain antibody fragments with high conformational stability. Protein Sci. 2002;11(3):500-515. doi:10.1110/ps.34602

17. Vuchelen A, O’Day E, De Genst E, et al. (1)H, (13)C and (15)N assignments of a camelid nanobody directed against human alpha-synuclein. Biomol NMR Assign. 2009;3(2):231-233. doi:10. 1007/s12104-009-9182-4

18. De Genst E, Silence K, Decanniere K, et al. Molecular basis for the preferential cleft recognition by dromedary heavy-chain antibodies. Proc Natl Acad Sci U S A. 2006;103(12):4586-4591. doi:10.1073/pnas.0505379103

19. Roshan R, Naderi S, Behdani M, et al. Isolation and characterization of nanobodies against epithelial cell adhesion molecule as novel theranostic agents for cancer therapy. Mol Immunol. 2021;129:70-77. doi:10.1016/j.molimm.2020.10.021

20. Bannas P, Hambach J, Koch-Nolte F. Nanobodies and nanobody-based human heavy chain antibodies as antitumor therapeutics. Front Immunol. 2017;8:1603. doi:10.3389/fimmu. 2017.01603

21. Kazemi-Lomedasht F, Behdani M, Rahimpour A, HabibiAnbouhi M, Poshang-Bagheri K, Shahbazzadeh D. Selection and characterization of specific nanobody against human immunoglobulin G. Monoclon Antib Immunodiagn Immunother. 2015;34(3):201-205. doi:10.1089/mab.2014.0086

22. Vaijayanthimala V, Cheng PY, Yeh SH, et al. The long-term stability and biocompatibility of fluorescent nanodiamond as an in vivo contrast agent. Biomaterials. 2012;33(31):7794-7802. doi:10.1016/j.biomaterials.2012.06.084

23. Teplyakov A, Obmolova G, Malia TJ, et al. Structural diversity in a human antibody germline library. MAbs. 2016;8(6):1045-1063. doi:10.1080/19420862.2016.1190060

24. Barthelemy PA, Raab H, Appleton BA, et al. Comprehensive analysis of the factors contributing to the stability and solubility of autonomous human VH domains. J Biol Chem. 2008;283 (6):3639-3654. doi:10.1074/jbc.M708536200

25. Arbabi Ghahroudi M, Desmyter A, Wyns L, Hamers R, Muyldermans S. Selection and identification of single domain antibody fragments from camel heavy-chain antibodies. FEBS Lett. 1997;414(3):521-526. doi:10.1016/S0014-5793(97)01062-4

26. Pérez JM, Renisio JG, Prompers JJ, et al. Thermal unfolding of a llama antibody fragment: a two-state reversible process. Biochemistry. 2001;40(1):74-83. doi:10.1021/bi0009082

27. Liu W, Song H, Chen Q, et al. Recent advances in the selection and identification of antigen-specific nanobodies. Mol Immunol. 2018;96:37-47. doi:10.1016/j.molimm.2018.02.012

28. Wang Y, Fan Z, Shao L, et al. Nanobody-derived nanobiotechnology tool kits for diverse biomedical and biotechnology applications. Int J Nanomedicine. 2016;11:3287-3303. doi:10.214 7/IJN.S107194

29. Unciti-Broceta JD, Del Castillo T, Soriano M, Magez S, GarciaSalcedo JA. Novel therapy based on camelid nanobodies. Ther Deliv. 2013;4(10):1321-1336. doi:10.4155/tde.13.87 
30. Duffy MJ, Crown J. Companion biomarkers: paving the pathway to personalized treatment for cancer. Clin Chem. 2013;59 (10):1447-1456. doi:10.1373/clinchem.2012.200477

31. Corraliza-Gorjón I, Somovilla-Crespo B, Santamaria S, Garcia-Sanz JA, Kremer L. New strategies using antibody combinations to increase cancer treatment effectiveness. Front Immunol. 2017;8:1804.

32. Ma H, O'Kennedy R. The structure of natural and recombinant antibodies. Methods Mol Biol. 2015;1348:7-11.

33. Allegra A, Innao V, Gerace D, Vaddinelli D, Allegra AG, Musolino C. Nanobodies and cancer: current status and new perspectives. Cancer Invest. 2018;36(4):221-237. doi:10.1080/ 07357907.2018.1458858

34. Harmsen MM, De Haard HJ. Properties, production, and applications of camelid single-domain antibody fragments. Appl Microbiol Biotechnol. 2007;77(1):13-22. doi:10.1007/s00253-007-1142-2

35. Marschall AL, Dübel S. Antibodies inside of a cell can change its outside: can intrabodies provide a new therapeutic paradigm? Comput Struct Biotechnol J. 2016;14:304-308. doi:10.1016/j. csbj.2016.07.003

36. Vercruysse T, Pardon E, Vanstreels E, Steyaert J, Daelemans D. An intrabody based on a llama single-domain antibody targeting the N-terminal alpha-helical multimerization domain of HIV-1 rev prevents viral production. J Biol Chem. 2010;285 (28):21768-21780. doi:10.1074/jbc.M110.112490

37. Yin W, Zhao Y, Kang X, et al. BBB-penetrating codelivery liposomes treat brain metastasis of non-small cell lung cancer with EGFR(T790M) mutation. Theranostics. 2020;10(14):6122-6135. doi: $10.7150 /$ thno. 42234

38. Hussack G, Hirama T, Ding W, Mackenzie R, Tanha J. Engineered single-domain antibodies with high protease resistance and thermal stability. PLoS One. 2011;6(11):e28218. doi:10.1371/journal.pone.0028218

39. Vandenbroucke K, de Haard H, Beirnaert E, et al. Orally administered L. lactis secreting an anti-TNF Nanobody demonstrate efficacy in chronic colitis. Mucosal Immunol. 2010;3(1):49-56. doi:10.1038/mi.2009.116

40. Maffey L, Vega CG, Miño S, Garaicoechea L, Parreño V. Anti-VP6 VHH: an experimental treatment for Rotavirus A-associated disease. PLoS One. 2016;11(9):e0162351. doi:10.1371/journal.pone.0162351

41. Huang L, Jiang S, Shi Y. Tyrosine kinase inhibitors for solid tumors in the past 20 years (2001-2020). J Hematol Oncol. 2020;13(1):143.

42. Liu Y, Scrivano L, Peterson JD, et al. EGFR-targeted nanobody functionalized polymeric micelles loaded with $\mathrm{mTHPC}$ for selective photodynamic therapy. Mol Pharm. 2020;17(4):1276-1292. doi:10.1021/acs.molpharmaceut.9b01280

43. Oliveira S, van Dongen GA, Stigter-van Walsum M, et al. Rapid visualization of human tumor xenografts through optical imaging with a near-infrared fluorescent anti-epidermal growth factor receptor nanobody. Mol Imaging. 2012;11(1):33-46. doi:10. 2310/7290.2011.00025

44. Gottlin EB, Xiangrong G, Pegram C, Cannedy A, Campa MJ, Patz EF Jr. Isolation of novel EGFR-specific VHH domains. J Biomol Screen. 2009;14(1):77-85. doi:10.1177/1087057108327064

45. Omidfar K, Amjad Zanjani FS, Hagh AG, Azizi MD, Rasouli SJ, Kashanian S. Efficient growth inhibition of EGFR over-expressing tumor cells by an anti-EGFR nanobody. Mol Biol Rep. 2013;40 (12):6737-6745. doi:10.1007/s11033-013-2790-1

46. $\mathrm{Hu}$ Y, Liu C, Muyldermans S. Nanobody-based delivery systems for diagnosis and targeted tumor therapy. Front Immunol. 2017;8:1442. doi:10.3389/fimmu.2017.01442

47. Oliveira S, Schiffelers RM, van der Veeken $J$, et al. Downregulation of EGFR by a novel multivalent nanobody-liposome platform. J Control Release. 2010;145 (2):165-175. doi:10.1016/j.jconrel.2010.03.020
48. Roovers RC, Laeremans T, Huang L, et al. Efficient inhibition of EGFR signaling and of tumour growth by antagonistic anti-EFGR nanobodies. Cancer Immunol Immunother. 2007;56(3):303-317.

49. Sebastian S, Settleman J, Reshkin SJ, Azzariti A, Bellizzi A, Paradiso A. The complexity of targeting EGFR signalling in cancer: from expression to turnover. Biochim Biophys Acta. 2006;1766(1):120-139.

50. Tijink BM, Laeremans T, Budde M, et al. Improved tumor targeting of anti-epidermal growth factor receptor nanobodies through albumin binding: taking advantage of modular nanobody technology. Mol Cancer Ther. 2008;7(8):2288-2297. doi:10.1158/1535-7163.MCT-07-2384

51. Hammarström S. The carcinoembryonic antigen (CEA) family: structures, suggested functions and expression in normal and malignant tissues. Semin Cancer Biol. 1999;9(2):67-81. doi:10.1006/scbi.1998.0119

52. Gray-Owen SD, Blumberg RS. CEACAM1: contact-dependent control of immunity. Nat Rev Immunol. 2006;6(6):433-446. doi:10.1038/nri1864

53. Cortez-Retamozo V, Backmann N, Senter PD, et al. Efficient cancer therapy with a nanobody-based conjugate. Cancer Res. 2004;64(8):2853-2857. doi:10.1158/0008-5472.CAN-03-3935

54. Shukla GS, Krag DN. Novel beta-lactamase-random peptide fusion libraries for phage display selection of cancer cell-targeting agents suitable for enzyme prodrug therapy. J Drug Target. 2010;18(2):115-124. doi:10.3109/ 10611860903244181

55. Wang H, Meng AM, Li SH, Zhou XL. A nanobody targeting carcinoembryonic antigen as a promising molecular probe for non-small cell lung cancer. Mol Med Rep. 2017;16(1):625-630. doi:10.3892/mmr.2017.6677

56. Nath S, Mukherjee P. MUC1: a multifaceted oncoprotein with a key role in cancer progression. Trends Mol Med. 2014;20 (6):332-342. doi:10.1016/j.molmed.2014.02.007

57. Gao T, Cen Q, Lei H. A review on development of MUC1-based cancer vaccine. Biomed Pharmacother. 2020;132:110888. doi:10.1016/j.biopha.2020.110888

58. Sadeqzadeh E, Rahbarizadeh F, Ahmadvand D, Rasaee MJ, Parhamifar L, Moghimi SM. Combined MUC1-specific nanobody-tagged PEG-polyethylenimine polyplex targeting and transcriptional targeting of tBid transgene for directed killing of MUC1 over-expressing tumour cells. J Control Release. 2011;156(1):85-91. doi:10.1016/j. jconrel.2011.06.022

59. Rezaei L, Shojaosadati SA, Farahmand L, Moradi-Kalbolandi S. Enhancement of extracellular bispecific anti-MUC1 nanobody expression in E. coli BL21 (DE3) by optimization of temperature and carbon sources through an autoinduction condition. Eng Life Sci. 2020;20(8):338-349. doi:10.1002/ elsc. 201900158

60. Rahbarizadeh F, Rasaee MJ, Forouzandeh M, Allameh AA. Over expression of anti-MUC1 single-domain antibody fragments in the yeast Pichia pastoris. Mol Immunol. 2006;43(5):426-435. doi:10.1016/j.molimm.2005.03.003

61. Rajabi-Memari H, Jalali-Javaran M, Rasaee MJ, Rahbarizadeh F, Forouzandeh-Moghadam M, Esmaili A. Expression and characterization of a recombinant single-domain monoclonal antibody against MUC1 mucin in tobacco plants. Hybridoma (Larchmt). 2006;25(4):209-215. doi:10.1089/hyb.2006.25.209

62. Wilkie S, Picco G, Foster J, et al. Retargeting of human T cells to tumor-associated MUC1: the evolution of a chimeric antigen receptor. J Immunol. 2008;180(7):4901-4909. doi:10.4049/ jimmunol.180.7.4901 
63. Rankin EB, Giaccia AJ. Hypoxic control of metastasis. Science. 2016;352(6282):175-180. doi:10.1126/science.aaf4405

64. Albanese A, Daly LA, Mennerich D, Kietzmann T, Sée V. The role of hypoxia-inducible factor post-translational modifications in regulating its localisation, stability, and activity. Int J Mol Sci. 2020;22(1):268. doi:10.3390/ijms22010268

65. Semenza GL. Targeting HIF-1 for cancer therapy. Nat Rev Cancer. 2003;3(10):721-732. doi:10.1038/nrc1187

66. Masoud GN, Li W. HIF-1 $\alpha$ pathway: role, regulation and intervention for cancer therapy. Acta Pharm Sin B. 2015;5(5): 378-389. doi:10.1016/j.apsb.2015.05.007

67. Groot AJ, Verheesen P, Westerlaken EJ, et al. Identification by phage display of single-domain antibody fragments specific for the ODD domain in hypoxia-inducible factor 1alpha. Lab Invest. 2006;86(4):345-356. doi:10.1038/labinvest.3700395

68. Fukumura D, Kloepper J, Amoozgar Z, Duda DG, Jain RK. Enhancing cancer immunotherapy using antiangiogenics: opportunities and challenges. Nat Rev Clin Oncol. 2018;15(5):325-340. doi:10.1038/nrclinonc.2018.29

69. Ding L, Tian C, Feng S, et al. Small sized EGFR1 and HER2 specific bifunctional antibody for targeted cancer therapy. Theranostics. 2015;5(4):378-398. doi:10.7150/thno.10084

70. Sha H, Zou Z, Xin K, et al. Tumor-penetrating peptide fused EGFR single-domain antibody enhances cancer drug penetration into 3D multicellular spheroids and facilitates effective gastric cancer therapy. J Control Release. 2015;200:188-200. doi:10.10 16/j.jconrel.2014.12.039

71. Van Impe $\mathrm{K}$, Bethuyne $\mathrm{J}$, Cool $\mathrm{S}$, et al. A nanobody targeting the F-actin capping protein CapG restrains breast cancer metastasis. Breast Cancer Res. 2013;15(6):R116. doi:10.1186/bcr3585

72. Adlere I, Caspar B, Arimont M, et al. Modulators of CXCR4 and CXCR7/ACKR3 Function. Mol Pharmacol. 2019;96(6):737-752. doi:10.1124/mol.119.117663

73. Wingler LM, McMahon C, Staus DP, Lefkowitz RJ, Kruse AC. Distinctive activation mechanism for angiotensin receptor revealed by a synthetic nanobody. Cell. 2019;176(3):479-490. e412. doi:10.1016/j.cell.2018.12.006

74. Bobkov V, Arimont M, Zarca A, et al. Antibodies targeting chemokine receptors CXCR4 and ACKR3. Mol Pharmacol. 2019;96(6):753-764. doi:10.1124/mol.119.116954

75. De Silva P, Aiello M, Gu-Trantien C, Migliori E, Willard-Gallo $\mathrm{K}$, Solinas C. Targeting CTLA-4 in cancer: is it the ideal companion for PD-1 blockade immunotherapy combinations? Int J Cancer. 2020. doi:10.1002/ijc.33415

76. Tang Z, Mo F, Liu A, et al. A nanobody against cytotoxic T-lymphocyte associated antigen-4 increases the anti-tumor effects of specific CD8(+) T cells. J Biomed Nanotechnol. 2019;15(11):2229-2239. doi:10.1166/jbn.2019.2859

77. Teicher BA, Fricker SP. CXCL12 (SDF-1)/CXCR4 pathway in cancer. Clin Cancer Res. 2010;16(11):2927-2931. doi:10.1158/ 1078-0432.CCR-09-2329

78. Jähnichen S, Blanchetot C, Maussang D, et al. CXCR4 nanobodies (VHH-based single variable domains) potently inhibit chemotaxis and HIV-1 replication and mobilize stem cells. Proc Natl Acad Sci US A. 2010;107(47):20565-20570. doi:10.1073/pnas.1012865107

79. Ramsey DM, McAlpine SR. Halting metastasis through CXCR4 inhibition. Bioorg Med Chem Lett. 2013;23(1):20-25. doi:10. 1016/j.bmcl.2012.10.138

80. Bobkov V, Zarca AM, Van Hout A, et al. Nanobody-Fc constructs targeting chemokine receptor CXCR4 potently inhibit signaling and CXCR4-mediated HIV-entry and induce antibody effector functions. Biochem Pharmacol. 2018;158:413-424. doi:10.1016/ j.bcp.2018.10.014
81. Ahmadvand D, Rasaee MJ, Rahbarizadeh F, Kontermann RE, Sheikholislami F. Cell selection and characterization of a novel human endothelial cell specific nanobody. Mol Immunol. 2009;46 (8-9):1814-1823. doi:10.1016/j.molimm.2009.01.021

82. Fonsatti E, Altomonte M, Nicotra MR, Natali PG, Maio M. Endoglin (CD105): a powerful therapeutic target on tumor-associated angiogenetic blood vessels. Oncogene. 2003;22 (42):6557-6563. doi:10.1038/sj.onc.1206813

83. Barboro P, Ferrari N, Balbi C. Emerging roles of heterogeneous nuclear ribonucleoprotein $\mathrm{K}$ (hnRNP $\mathrm{K}$ ) in cancer progression. Cancer Lett. 2014;352(2):152-159. doi:10.1016/j.canlet.2014.06.019

84. Inoue A, Sawata SY, Taira K, Wadhwa R. Loss-of-function screening by randomized intracellular antibodies: identification of hnRNP-K as a potential target for metastasis. Proc Natl Acad Sci U S A. 2007;104 (21):8983-8988. doi:10.1073/pnas.0607595104

85. Rahbarizadeh F, Ahmadvand D, Sharifzadeh Z. Nanobody; an old concept and new vehicle for immunotargeting. Immunol Invest. 2011;40(3):299-338. doi:10.3109/08820139.2010.542228

86. Crowe JS, Roberts KJ, Carlton TM, et al. Preclinical development of a novel, orally-administered anti-tumour necrosis factor domain antibody for the treatment of inflammatory bowel disease. Sci Rep. 2018;8 (1):4941. doi:10.1038/s41598-018-23277-7

87. Groot AJ, El Khattabi M, Sachs N, et al. Reverse proteomic antibody screening identifies anti adhesive VHH targeting VLA-3. Mol Immunol. 2009;46(10):2022-2028. doi:10.1016/j. molimm.2009.03.002

88. Wu W, Li S, Zhang W, Sun J, Ren G, Dong Q. A novel VHH antibody targeting the B cell-activating factor for B-cell lymphoma. Int J Mol Sci. 2014;15(6):9481-9496. doi:10.3390/ ijms 15069481

89. Mimori K, Kiyokawa N, Taguchi T, et al. Costimulatory signals distinctively affect CD20- and B-cell-antigen-receptor-mediated apoptosis in Burkitt's lymphoma/leukemia cells. Leukemia. 2003;17(6):1164-1174. doi:10.1038/sj.leu.2402936

90. Hambach J, Riecken K, Cichutek S, et al. Targeting CD38-expressing multiple myeloma and burkitt lymphoma cells in vitro with nanobody-based chimeric antigen receptors (Nb-CARs). Cells. 2020;9(2):321. doi:10.3390/cells9020321

91. Fumey W, Koenigsdorf J, Kunick V, et al. Nanobodies effectively modulate the enzymatic activity of CD38 and allow specific imaging of CD38(+) tumors in mouse models in vivo. Sci Rep. 2017;7(1):14289. doi:10.1038/s41598-017-14112-6

92. Bannas P, Koch-Nolte F. Perspectives for the development of CD38-specific heavy chain antibodies as therapeutics for multiple myeloma. Front Immunol. 2018;9:2559. doi:10.3389/fimmu.20 18.02559

93. Del Rosario JMM, Smith M, Zaki K, et al. Protection from influenza by intramuscular gene vector delivery of a broadly neutralizing nanobody does not depend on antibody dependent cellular cytotoxicity. Front Immunol. 2020;11:627. doi:10.3389/ fimmu.2020.00627

94. Fang T, Duarte JN, Ling J, Li Z, Guzman JS, Ploegh HL. Structurally defined $\alpha \mathrm{MHC}$-II nanobody-drug conjugates: a therapeutic and imaging system for B-cell lymphoma. Angew Chem Int Ed Engl. 2016;55(7):2416-2420. doi:10.1002/ anie. 201509432

95. Nieberler M, Reuning U, Reichart F, et al. Exploring the role of RGD-recognizing integrins in cancer. Cancers (Basel). 2017;9 (12):116. doi:10.3390/cancers9090116

96. Yan H, You Y, Li X, et al. Preparation of RGD peptide/folate acid double-targeted mesoporous silica nanoparticles and its application in human breast cancer MCF-7 cells. Front Pharmacol. 2020;11:898. doi:10.3389/fphar.2020.00898 
97. Singh S, Kumar NK, Dwiwedi P, et al. Monoclonal antibodies: a review. Curr Clin Pharmacol. 2018;13(2):85-99. doi:10.2174/ 1574884712666170809124728

98. Van Audenhove I, Gettemans J. Nanobodies as versatile tools to understand, diagnose, visualize and treat cancer. EBioMedicine. 2016;8:40-48. doi:10.1016/j.ebiom.2016.04.028

99. Siontorou CG. Nanobodies as novel agents for disease diagnosis and therapy. Int J Nanomedicine. 2013;8:4215-4227. doi:10.21 47/IJN.S39428

100. Nakamura T, Harashima $H$. Integration of nano drug-delivery system with cancer immunotherapy. Ther Deliv. 2017;8 (11):987-1000. doi:10.4155/tde-2017-0071

101. Zhao H, Li Y, Wei D, Luo H. The application of nanoparticle-based drug delivery systems in checkpoint blockade cancer immunotherapy. J Immunol Res. 2018;2018:3673295. doi: $10.1155 / 2018 / 3673295$

102. Kratz F, Warnecke A. Finding the optimal balance: challenges of improving conventional cancer chemotherapy using suitable combinations with nano-sized drug delivery systems. J Control Release. 2012;164(2):221-235. doi:10.1016/j. jconrel.2012.05.045

103. Wu T, Liu J, Liu M, et al. A nanobody-conjugated DNA nanoplatform for targeted platinum-drug delivery. Angew Chem Int Ed Engl. 2019;58(40):14224-14228. doi:10.1002/anie.201909345

104. Debets MF, Leenders WP, Verrijp K, et al. Nanobodyfunctionalized polymersomes for tumor-vessel targeting. Macromol Biosci. 2013;13(7):938-945. doi:10.1002/mabi.20130 0039

105. Huang P, Wang X, Liang X, et al. Nano-, micro-, and macroscale drug delivery systems for cancer immunotherapy. Acta Biomater. 2019;85:1-26. doi:10.1016/j.actbio.2018.12.028

106. Felice B, Prabhakaran MP, Rodríguez AP, Ramakrishna S. Drug delivery vehicles on a nano-engineering perspective. Mater Sci Eng C Mater Biol Appl. 2014;41:178-195. doi:10.1016/j.msec.20 14.04.049

107. van der Meel R, Oliveira S, Altintas I, et al. Tumor-targeted nanobullets: anti-EGFR nanobody-liposomes loaded with anti-IGF-1R kinase inhibitor for cancer treatment. $J$ Control Release. 2012;159(2):281-289. doi:10.1016/j.jconrel.2011.12.027

108. Talelli M, Oliveira S, Rijcken CJ, et al. Intrinsically active nanobody-modified polymeric micelles for tumor-targeted combination therapy. Biomaterials. 2013;34(4):1255-1260. doi:10.10 16/j.biomaterials.2012.09.064

109. Elzoghby AO, Samy WM, Elgindy NA. Albumin-based nanoparticles as potential controlled release drug delivery systems. $J$ Control Release. 2012;157(2):168-182. doi:10.1016/j.jconrel.2011.07.031

110. Van de Broek B, Devoogdt N, D'Hollander A, et al. Specific cell targeting with nanobody conjugated branched gold nanoparticles for photothermal therapy. ACS Nano. 2011;5(6):4319-4328. doi:10.1021/nn1023363

111. Talelli M, Rijcken CJ, Oliveira S, et al. Reprint of "Nanobodyshell functionalized thermosensitive core-crosslinked polymeric micelles for active drug targeting". J Control Release. 2011;153 (1):93-102. doi:10.1016/j.jconrel.2011.06.003

112. Oliveira S, Heukers R, Sornkom J, Kok RJ, van Bergen En Henegouwen PM. Targeting tumors with nanobodies for cancer imaging and therapy. $J$ Control Release. 2013;172(3):607-617. doi:10.1016/j.jconrel.2013.08.298

113. Steeland S, Vandenbroucke RE, Libert C. Nanobodies as therapeutics: big opportunities for small antibodies. Drug Discov Today. 2016;21(7):1076-1113.

114. Behdani M, Zeinali S, Karimipour $M$, et al. Development of VEGFR2-specific Nanobody Pseudomonas exotoxin A conjugated to provide efficient inhibition of tumor cell growth. $N$ Biotechnol. 2013;30(2):205-209. doi:10.1016/j.nbt.2012.09.002
115. Wu T, Huang H, Sheng Y, Shi H, Min Y, Liu Y. Transglutaminase mediated PEGylation of nanobodies for targeted nano-drug delivery. J Mater Chem B. 2018;6(7):1011-1017. doi:10.1039/ C7TB03132G

116. van de Water JA, Bagci-Onder T, Agarwal AS, et al. Therapeutic stem cells expressing variants of EGFR-specific nanobodies have antitumor effects. Proc Natl Acad Sci U S A. 2012;109(41): 16642-16647. doi:10.1073/pnas. 1202832109

117. Gray MA, Tao RN, DePorter SM, Spiegel DA, McNaughton BR. A nanobody activation immunotherapeutic that selectively destroys HER2-positive breast cancer cells. Chembiochem. 2016;17(2):155-158. doi:10.1002/cbic.201500591

118. Martínez-Jothar L, Beztsinna N, van Nostrum CF, Hennink WE, Oliveira S. Selective cytotoxicity to HER2 positive breast cancer cells by saporin-loaded nanobody-targeted polymeric nanoparticles in combination with photochemical internalization. Mol Pharm. 2019;16(4):1633-1647. doi:10.1021/acs. molpharmaceut.8b01318

119. Arias JL, Unciti-Broceta JD, Maceira J, et al. Nanobody conjugated PLGA nanoparticles for active targeting of African Trypanosomiasis. J Control Release. 2015;197:190-198. doi:10. 1016/j.jconrel.2014.11.002

120. Costa SA, Mozhdehi D, Dzuricky MJ, Isaacs FJ, Brustad EM, Chilkoti A. Active targeting of cancer cells by nanobody decorated polypeptide micelle with bio-orthogonally conjugated drug. Nano Lett. 2019;19(1):247-254. doi:10.1021/acs.nanolett.8b0 3837

121. Acharya S, Dilnawaz F, Sahoo SK. Targeted epidermal growth factor receptor nanoparticle bioconjugates for breast cancer therapy. Biomaterials. 2009;30(29):5737-5750. doi:10.1016/j. biomaterials.2009.07.008

122. Noor A, Walser G, Wesseling $\mathrm{M}$, et al. Production of a mono-biotinylated EGFR nanobody in the E. coli periplasm using the pET22b vector. BMC Res Notes. 2018;11(1):751. doi:10.1186/s13104-018-3852-1

123. Vivekanadhan S, Mukhopadhyay D. Divergent roles of Plexin D1 in cancer. Biochim Biophys Acta Rev Cancer. 2019;1872 (1):103-110. doi:10.1016/j.bbcan.2019.05.004

124. Lecocq Q, De Vlaeminck Y, Hanssens H, et al. Theranostics in immuno-oncology using nanobody derivatives. Theranostics. 2019;9(25):7772-7791. doi:10.7150/thno.34941

125. Fridy PC, Li Y, Keegan S, et al. A robust pipeline for rapid production of versatile nanobody repertoires. Nat Methods. 2014;11(12):1253-1260. doi:10.1038/nmeth.3170

126. Williams SC. Small nanobody drugs win big backing from pharma. Nat Med. 2013;19(11):1355-1356. doi:10.1038/nm11 13-1355

127. Pérez-Herrero E, Fernández-Medarde A. Advanced targeted therapies in cancer: drug nanocarriers, the future of chemotherapy. Eur J Pharm Biopharm. 2015;93:52-79.

128. Zottel A, Videtič Paska A, Jovčevska I. Nanotechnology meets oncology: nanomaterials in brain cancer research, diagnosis and therapy. Materials (Basel). 2019;12(10):1588. doi:10.3390/ma12 101588

129. Glassman PM, Walsh LR, Villa CH, et al. Molecularly engineered nanobodies for tunable pharmacokinetics and drug delivery. Bioconjug Chem. 2020;31(4):1144-1155. doi:10.1021/acs. bioconjchem.0c00003

130. Goldsmith SJ. Targeted radionuclide therapy: a historical and personal review. Semin Nucl Med. 2020;50(1):87-97. doi:10.10 53/j.semnuclmed.2019.07.006

131. Wiseman GA, White CA, Witzig TE, et al. Radioimmunotherapy of relapsed non-Hodgkin's lymphoma with zevalin, a 90Y-labeled anti-CD20 monoclonal antibody. Clin Cancer Res. 1999;5(10 Suppl):3281s-3286s. 
132. Gill MR, Falzone N, Du Y, Vallis KA. Targeted radionuclide therapy in combined-modality regimens. Lancet Oncol. 2017;18 (7):e414-e423. doi:10.1016/S1470-2045(17)30379-0

133. Sgouros G, Bodei L, McDevitt MR, Nedrow JR. Radiopharmaceutical therapy in cancer: clinical advances and challenges. Nat Rev Drug Discov. 2020;19(9):589-608.

134. Bolli E, D'Huyvetter M, Murgaski A, et al. Stromal-targeting radioimmunotherapy mitigates the progression of therapy-resistant tumors. J Control Release. 2019;314:1-11. doi:10.1016/j.jconrel.2019.10.024

135. D'Huyvetter M, Vincke $\mathrm{C}$, Xavier $\mathrm{C}$, et al. Targeted radionuclide therapy with A 177Lu-labeled anti-HER2 nanobody. Theranostics. 2014;4(7):708-720. doi:10.7150/thno.8156

136. D'Huyvetter M, Aerts A, Xavier C, et al. Development of 177Lu-nanobodies for radioimmunotherapy of HER2-positive breast cancer: evaluation of different bifunctional chelators. Contrast Media Mol Imaging. 2012;7(2):254-264. doi:10.1002/cmmi.491

137. D'Huyvetter M, Xavier C, Caveliers V, Lahoutte T, Muyldermans S, Devoogdt N. Radiolabeled nanobodies as theranostic tools in targeted radionuclide therapy of cancer. Expert Opin Drug Deliv. 2014;11(12):1939-1954. doi:10.1517/ 17425247.2014.941803

138. Donohoe C, Senge MO, Arnaut LG, Gomes-da-silva LC. Cell death in photodynamic therapy: from oxidative stress to anti-tumor immunity. Biochim Biophys Acta Rev Cancer. 2019;1872(2):188308. doi:10.1016/j.bbcan.2019.07.003

139. Chudy M, Tokarska K, Jastrzębska E, et al. Lab-on-a-chip systems for photodynamic therapy investigations. Biosens Bioelectron. 2018;101:37-51. doi:10.1016/j.bios.2017.10.013

140. He Y, Cong C, Li X, et al. Nano-drug system based on hierarchical drug release for deep localized/systematic cascade tumor therapy stimulating antitumor immune responses. Theranostics. 2019;9(10):2897-2909. doi:10.7150/thno.33534

141. Deken MM, Kijanka MM, Beltrán Hernández I, et al. Nanobodytargeted photodynamic therapy induces significant tumor regression of trastuzumab-resistant HER2-positive breast cancer, after a single treatment session. J Control Release. 2020;323:269-281. doi:10.1016/j.jconrel.2020.04.030

142. van Driel P, Boonstra MC, Slooter MD, et al. EGFR targeted nanobody-photosensitizer conjugates for photodynamic therapy in a pre-clinical model of head and neck cancer. $J$ Control Release. 2016;229:93-105. doi:10.1016/j.jconrel.2016.03.014

143. Yin W, Yu X, Kang X, et al. Remodeling tumor-associated macrophages and neovascularization overcomes EGFR(T790M)-associated drug resistance by PD-L1 nanobody-mediated codelivery. Small. 2018;14(47):e1802372. doi:10.1002/smll.201802372

144. Qiao J, Fu YX. Cytokines that target immune killer cells against tumors. Cell Mol Immunol. 2020;17(7):722-727. doi:10.1038/ s41423-020-0481-0

145. Varadé J, Magadán S, González-Fernández Á. Human immunology and immunotherapy: main achievements and challenges. Cell Mol Immunol. 2020:1-24.

146. Rozan C, Cornillon A, Pétiard C, et al. Single-domain antibodybased and linker-free bispecific antibodies targeting Fc $\gamma$ RIII induce potent antitumor activity without recruiting regulatory T cells. Mol Cancer Ther. 2013;12(8):1481-1491. doi:10.1158/ 1535-7163.MCT-12-1012

147. Hollandsworth HM, Amirfakhri S, Filemoni F, et al. Nearinfrared photoimmunotherapy is effective treatment for colorectal cancer in orthotopic nude-mouse models. PLoS One. 2020;15(6): e0234643. doi:10.1371/journal.pone.0234643

148. Zhang Y, Zhang Z. The history and advances in cancer immunotherapy: understanding the characteristics of tumor-infiltrating immune cells and their therapeutic implications. Cell Mol Immunol. 2020;17(8):807-821.
149. Xie YJ, Dougan M, Jailkhani N, et al. Nanobody-based CAR $\mathrm{T}$ cells that target the tumor microenvironment inhibit the growth of solid tumors in immunocompetent mice. Proc Natl Acad Sci U S A. 2019;116(16):7624-7631. doi:10.1073/pnas.1817147116

150. Yong SB, Chung JY, Song Y, Kim J, Ra S, Kim YH. Non-viral nano-immunotherapeutics targeting tumor microenvironmental immune cells. Biomaterials. 2019;219:119401. doi:10.1016/j. biomaterials.2019.119401

151. Gorovits B, Koren E. Immunogenicity of chimeric antigen receptor T-cell therapeutics. BioDrugs. 2019;33(3):275-284. doi:10.10 07/s40259-019-00354-5

152. Xie YJ, Dougan M, Ingram JR, et al. Improved antitumor efficacy of chimeric antigen receptor $\mathrm{T}$ Cells that secrete single-domain antibody fragments. Cancer Immunol Res. 2020;8(4):518-529. doi:10.1158/2326-6066.CIR-19-0734

153. Sharifzadeh Z, Rahbarizadeh F, Shokrgozar MA, et al. Genetically engineered $\mathrm{T}$ cells bearing chimeric nanoconstructed receptors harboring TAG-72-specific camelid single domain antibodies as targeting agents. Cancer Lett. 2013;334(2):237-244. doi:10.1016/j.canlet.2012.08.010

154. De Munter S, Van Parys A, Bral L, et al. Rapid and effective generation of nanobody based CARs using PCR and gibson assembly. Int J Mol Sci. 2020;21(3):883. doi:10.3390/ijms21030883

155. Zhang G, Wang L, Cui H, et al. Anti-melanoma activity of T cells redirected with a TCR-like chimeric antigen receptor. Sci Rep. 2014;4:3571. doi:10.1038/srep03571

156. Newick K, O’Brien S, Moon E, Albelda SM. CAR T cell therapy for solid tumors. Annu Rev Med. 2017;68:139-152. doi:10.1146/ annurev-med-062315-120245

157. Jailkhani N, Ingram JR, Rashidian M, et al. Noninvasive imaging of tumor progression, metastasis, and fibrosis using a nanobody targeting the extracellular matrix. Proc Natl Acad Sci U S A. 2019;116(28):14181-14190. doi:10.1073/pnas.1817442116

158. Hassani M, Hajari Taheri F, Sharifzadeh Z, et al. Construction of a chimeric antigen receptor bearing a nanobody against prostate a specific membrane antigen in prostate cancer. $J$ Cell Biochem. 2019;120(6):10787-10795. doi:10.1002/jcb.28370

159. Kagoya Y, Tanaka S, Guo T, et al. A novel chimeric antigen receptor containing a JAK-STAT signaling domain mediates superior antitumor effects. Nat Med. 2018;24(3):352-359. doi:10.1038/nm.4478

160. Astrof S, Hynes RO. Fibronectins in vascular morphogenesis. Angiogenesis. 2009;12(2):165-175. doi:10.1007/s10456-009-9136-6

161. Keir ME, Butte MJ, Freeman GJ, Sharpe AH. PD-1 and its ligands in tolerance and immunity. Annu Rev Immunol. 2008;26:677-704. doi:10.1146/annurev.immunol.26.021607.090331

162. Frey N, Porter D. Cytokine release syndrome with chimeric antigen receptor T cell therapy. Biol Blood Marrow Transplant. 2019;25(4):e123-e127. doi:10.1016/j.bbmt.2018.12.756

163. Helsen CW, Hammill JA, Lau VWC, et al. The chimeric TAC receptor co-opts the $\mathrm{T}$ cell receptor yielding robust anti-tumor activity without toxicity. Nat Commun. 2018;9(1):3049. doi:10. 1038/s41467-018-05395-y

164. Walseng E, Köksal H, Sektioglu IM, et al. A TCR-based chimeric antigen receptor. Sci Rep. 2017;7(1):10713. doi:10.1038/s41598-01711126-y

165. Yang X, Xie S, Yang X, et al. Opportunities and challenges for antibodies against intracellular antigens. Theranostics. 2019;9 (25):7792-7806. doi:10.7150/thno.35486

166. Wu L, Wei Q, Brzostek J, Gascoigne NRJ. Signaling from T cell receptors (TCRs) and chimeric antigen receptors (CARs) on T cells. Cell Mol Immunol. 2020;17(6):600-612. doi:10.1038/s41423-0200470-3

167. Hardy IR, Schamel WW, Baeuerle PA, Getts DR, Hofmeister R. Implications of $\mathrm{T}$ cell receptor biology on the development of new $\mathrm{T}$ cell therapies for cancer. Immunotherapy. 2020;12(1):89-103. 
168. Muyldermans S. Nanobodies: natural single-domain antibodies. Annu Rev Biochem. 2013;82:775-797. doi:10.1146/annurevbiochem-063011-092449

169. De Meyer T, Muyldermans S, Depicker A. Nanobody-based products as research and diagnostic tools. Trends Biotechnol. 2014;32(5):263-270. doi:10.1016/j.tibtech.2014.03.001

170. Sukhanova A, Even-Desrumeaux K, Kisserli A, et al. Oriented conjugates of single-domain antibodies and quantum dots: toward a new generation of ultrasmall diagnostic nanoprobes. Nanomedicine. 2012;8(4):516-525. doi:10.1016/j.nano.2011.07.007

171. Dolk E, van der Vaart M, Lutje Hulsik D, et al. Isolation of llama antibody fragments for prevention of dandruff by phage display in shampoo. Appl Environ Microbiol. 2005;71(1):442-450. doi:10. 1128/AEM.71.1.442-450.2005

172. Kümmerer K. Significance of antibiotics in the environment. J Antimicrob Chemother. 2003;52(1):5-7. doi:10.1093/jac/dkg293

173. Arbabi-Ghahroudi M. Camelid single-domain antibodies: historical perspective and future outlook. Front Immunol. 2017;8:1589. doi:10.3389/fimmu.2017.01589

174. Arezumand R, Alibakhshi A, Ranjbari J, Ramazani A, Muyldermans S. Nanobodies as novel agents for targeting angiogenesis in solid cancers. Front Immunol. 2017;8:1746. doi:10.3389/ fimmu. 2017.01746

175. Zhu H, Zhao L, Li Z, et al. Preparation and characterization of humanized nanobodies targeting the dimer interface of epidermal growth factor receptor (EGFR). Protein Expr Purif. 2019; 157:57-62. doi:10.1016/j.pep.2019.02.003

176. Ma L, Gu K, Zhang CH, et al. Generation and characterization of a human nanobody against VEGFR-2. Acta Pharmacol Sin. 2016;37(6):857-864. doi:10.1038/aps.2016.2

177. Ebrahimizadeh W, Mousavi Gargari SL, Javidan Z, Rajabibazl M. Production of novel VHH nanobody inhibiting angiogenesis by targeting binding site of VEGF. Appl Biochem Biotechnol. 2015;176(7):1985-1995. doi:10.1007/s12010-015-1695-y

178. Slørdahl TS, Denayer T, Moen SH, et al. Anti-c-MET Nanobody a new potential drug in multiple myeloma treatment. Eur J Haematol. 2013;91(5):399-410. doi:10.1111/ejh.12185

179. Maussang D, Mujić-Delić A, Descamps FJ, et al. Llama-derived single variable domains (nanobodies) directed against chemokine receptor CXCR7 reduce head and neck cancer cell growth in vivo. J Biol Chem. 2013;288(41):29562-29572. doi:10.1074/jbc.M113.498436

180. Fernandes JC. Therapeutic application of antibody fragments in autoimmune diseases: current state and prospects. Drug Discov Today. 2018;23(12):1996-2002. doi:10.1016/j.drudis.2018.06.003

181. Roovers RC, Vosjan MJ, Laeremans T, et al. A biparatopic anti-EGFR nanobody efficiently inhibits solid tumour growth. Int J Cancer. 2011;129(8):2013-2024. doi:10.1002/ijc.26145

182. Scully M, Cataland SR, Peyvandi F, et al. Caplacizumab treatment for acquired thrombotic thrombocytopenic purpura. $N$ Engl $J$ Med. 2019;380(4):335-346.

183. Stéen EJL, Edem PE, Nørregaard K, et al. Pretargeting in nuclear imaging and radionuclide therapy: improving efficacy of theranostics and nanomedicines. Biomaterials. 2018;179:209-245.
184. Rissiek B, Koch-Nolte F, Magnus T. Nanobodies as modulators of inflammation: potential applications for acute brain injury. Front Cell Neurosci. 2014;8:344. doi:10.3389/fncel.2014.00344

185. Gai J, Ma L, Li G, et al. A potent neutralizing nanobody against SARS-CoV-2 with inhaled delivery potential. bioRxiv. 2020.

186. Jovčevska I, Muyldermans S. The therapeutic potential of nanobodies. BioDrugs. 2020;34(1):11-26. doi:10.1007/s40259019-00392-z

187. Sheridan C. Llama-inspired antibody fragment approved for rare blood disorder. Nat Biotechnol. 2019;37(4):333-334. doi:10.10 38/s41587-019-0101-7

188. Duggan S. Caplacizumab: first global approval. Drugs. 2018;78 (15):1639-1642. doi:10.1007/s40265-018-0989-0

189. Svecova D, Lubell MW, Casset-Semanaz F, Mackenzie H, Grenningloh R, Krueger JG. A randomized, double-blind, placebo-controlled Phase 1 study of multiple ascending doses of subcutaneous M1095, an anti-interleukin 17A/F nanobody, in moderate-to-severe psoriasis. J Am Acad Dermatol. 2019;81 (1):196-203. doi:10.1016/j.jaad.2019.03.056

190. Van Roy M, Ververken C, Beirnaert E, et al. The preclinical pharmacology of the high affinity anti-IL-6R Nanobody ${ }^{\circledR}$ ALX0061 supports its clinical development in rheumatoid arthritis. Arthritis Res Ther. 2015;17(1):135. doi:10.1186/s13075-0150651-0

191. Siebuhr AS, Werkmann D, Bay-Jensen AC, et al. The antiADAMTS-5 Nanobody $\left({ }^{\circledR}\right)$ M6495 protects cartilage degradation ex vivo. Int J Mol Sci. 2020;21(17):5992. doi:10.3390/ijms21 175992

192. De Munter S, Ingels J, Goetgeluk G, et al. Nanobody based dual specific CARs. Int J Mol Sci. 2018;19(2):403. doi:10.3390/ ijms19020403

193. Cunningham S, Piedra PA, Martinon-Torres F, et al. Nebulised ALX-0171 for respiratory syncytial virus lower respiratory tract infection in hospitalised children: a double-blind, randomised, placebo-controlled, phase 2b trial. Lancet Respir Med. 2021;9 (1):21-32. doi:10.1016/S2213-2600(20)30320-9

194. Tyagarajan S, Spencer, Smith J. Optimizing CAR-T Cell Manufacturing Processes during Pivotal Clinical Trials. MOI Ther Methods Clin Dev. 2020;16:136-144.

195. Maus MV, Levine BL.. Chimeric antigen receptor T-cell therapy for the community oncologist. Oncologist. 2016;21(5):608-617. doi:10.1634/theoncologist.2015-0421

196. Muyldermans S. Single domain camel antibodies: current status. $J$ Biotechnol. 2001;74(4):277-302. doi:10.1016/s1389-0352(01) 00021-6

197. Wang F, Zhang L, Bai X, et al. Stimuli-responsive nanocarrier for co-delivery of MiR-31 and doxorubicin to suppress high MtEF4 cancer. ACS Appl Mater Interfaces. 2018;10(26):22767-22775. doi:10.1021/acsami.8b07698

198. Li Z, Xiao C, Yong T, Li Z, Gan L, Yang X. Influence of nanomedicine mechanical properties on tumor targeting delivery. Chem Soc Rev. 2020;49(8):2273-2290. doi:10.1039/ C9CS00575G
International Journal of Nanomedicine

\section{Publish your work in this journal}

The International Journal of Nanomedicine is an international, peerreviewed journal focusing on the application of nanotechnology in diagnostics, therapeutics, and drug delivery systems throughout the biomedical field. This journal is indexed on PubMed Central, MedLine, CAS, SciSearch ${ }^{\mathbb{R}}$, Current Contents ${ }^{\mathbb{R}} /$ Clinical Medicine, $^{2}$
Journal Citation Reports/Science Edition, EMBase, Scopus and the Elsevier Bibliographic databases. The manuscript management system is completely online and includes a very quick and fair peer-review system, which is all easy to use. Visit http://www.dovepress.com/ testimonials.php to read real quotes from published authors. 